\title{
Groundwater Budgets for Detrital, Hualapai, and Sacramento Valleys, Mohave County, Arizona, 2007-08
}

Scientific thin es igations Report $2011-5159$

Us. Department of line interior U.S. Geological sing tre

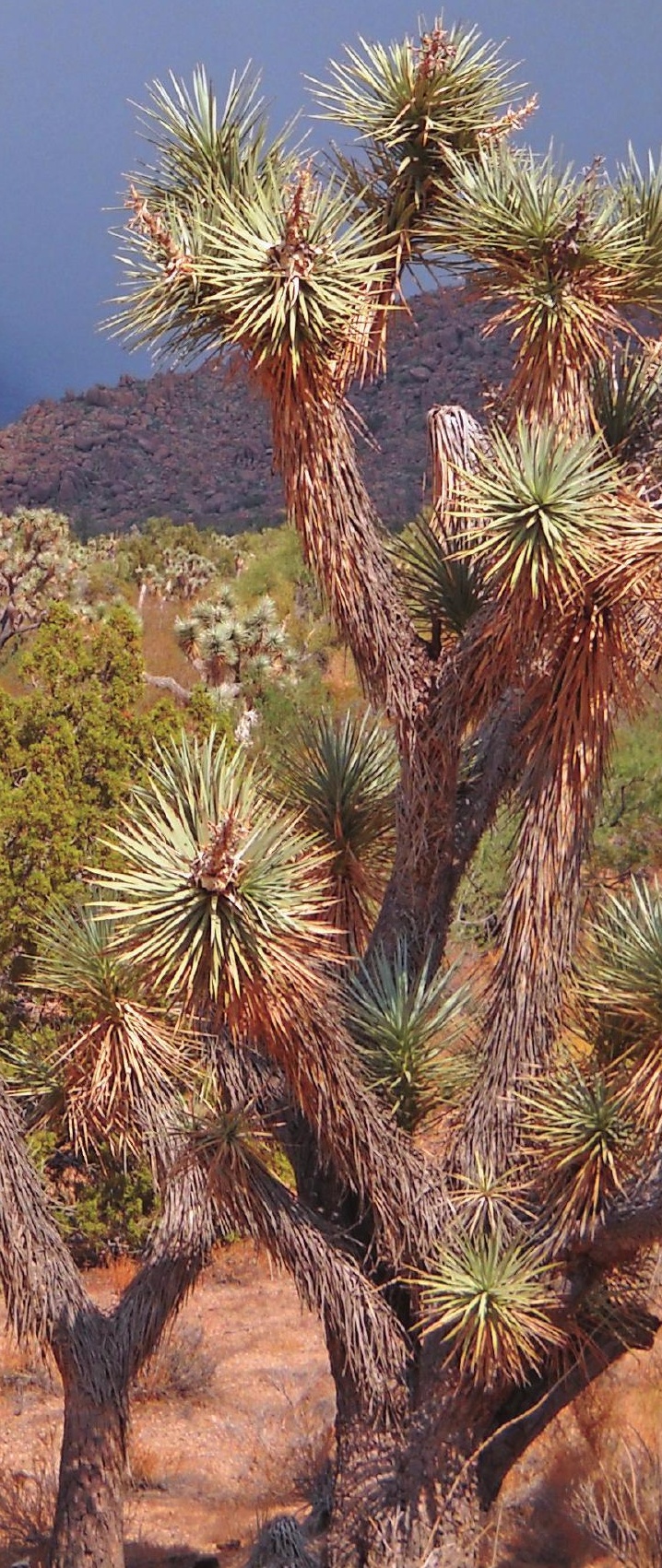


COVER:

View of August 2010, monsoon thunderstorm over Hualapai Mountains, looking east from Sacramento Valley. Photo by Bradley D. Garner. 
Prepared in cooperation with the Arizona Department of Water Resources

Groundwater Budgets for Detrital, Hualapai, and Sacramento Valleys, Mohave County, Arizona, 2007-08

By Bradley D. Garner and Margot Truini

Scientific Investigations Report 2011-5159 


\section{U.S. Department of the Interior \\ KEN SALAZAR, Secretary \\ U.S. Geological Survey \\ Marcia K. McNutt, Director}

U.S. Geological Survey, Reston, Virginia: 2011

For product and ordering information:

World Wide Web: http://www.usgs.gov/pubprod

Telephone: 1-888-ASK-USGS

For more information on the USGS - the Federal source for science about the Earth, its natural and living resources, natural hazards, and the environment:

World Wide Web: http://www.usgs.gov

Telephone: 1-888-ASK-USGS

Any use of trade, product, or firm names is for descriptive purposes only and does not imply endorsement by the U.S. Government.

Although this report is in the public domain, permission must be secured from the individual copyright owners to reproduce any copyrighted material contained within this report.

Suggested citation:

Garner, B.D., and Truini, Margot, 2011, Groundwater budgets for Detrital, Hualapai, and Sacramento Valleys, Mohave County, Arizona, 2007-08: U.S. Geological Survey Scientific Investigations Report 2011-5159, 34 p. 


\section{Acknowledgments}

The authors thank Jeff Corwin and George Sedich, City of Kingman, and Brian Henderson, Griffith Power LLC, who provided helpful information about the use and disposal of water within the study area. The authors also thank businesses and water suppliers who provided groundwater-withdrawal data to State agencies and provided verification of values when requested. 
This page left intentionally blank. 


\section{Contents}

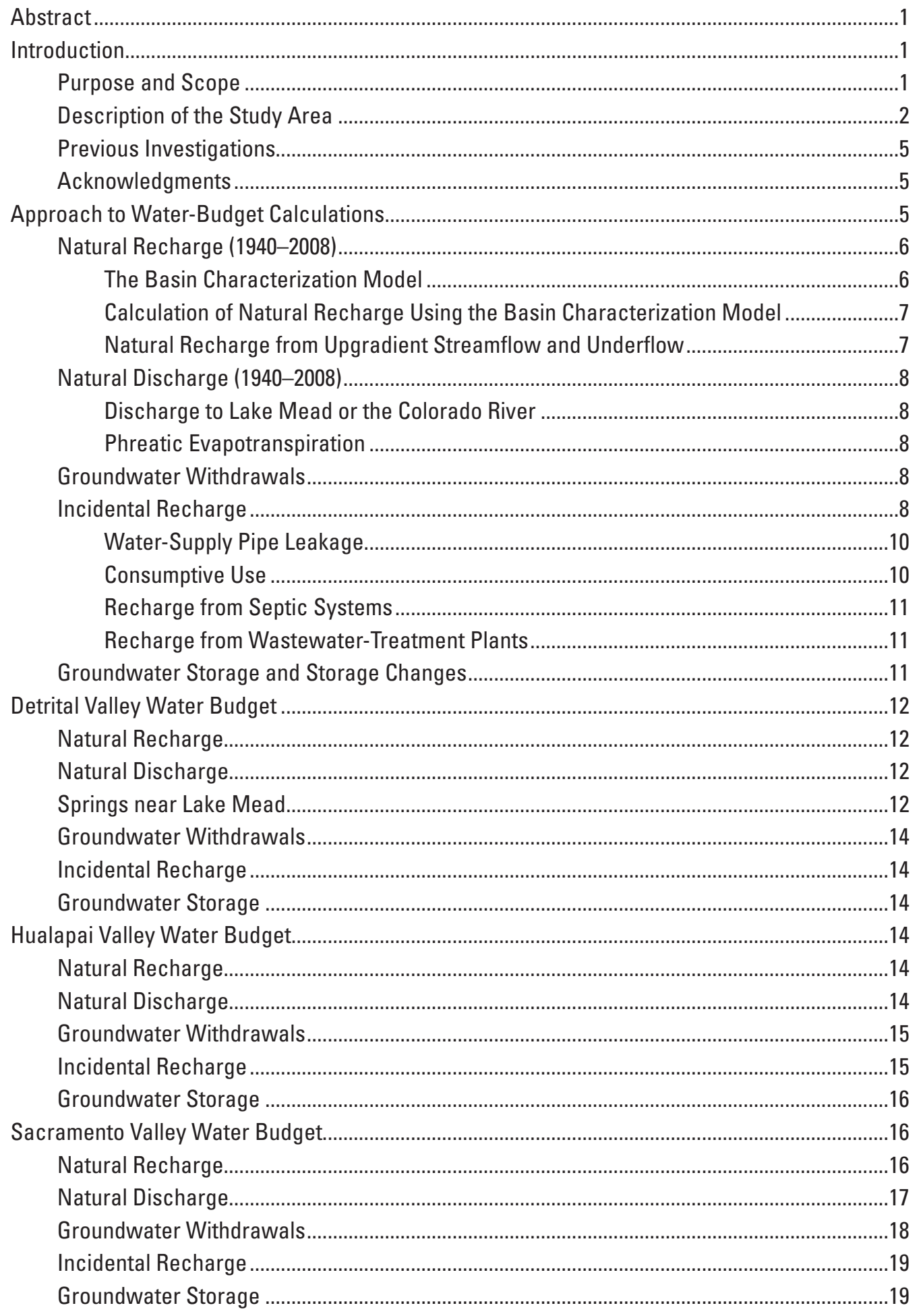




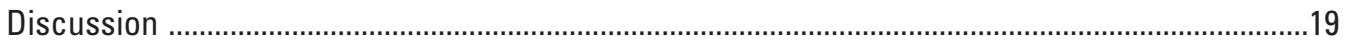

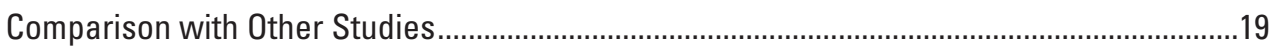

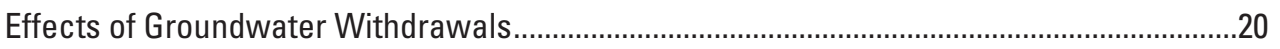

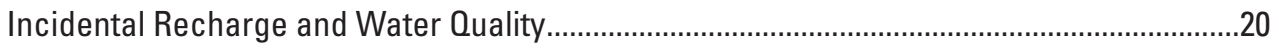

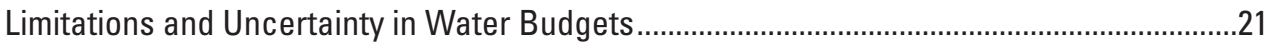

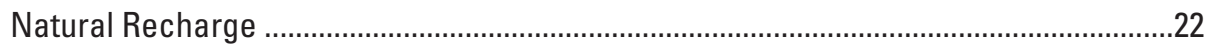

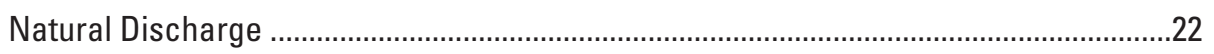

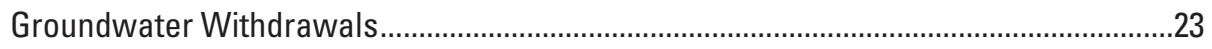

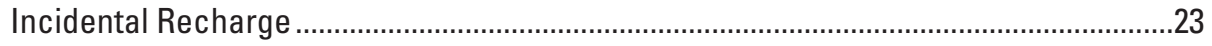

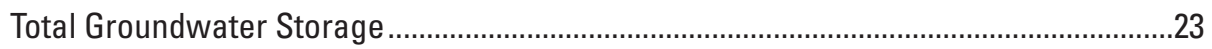

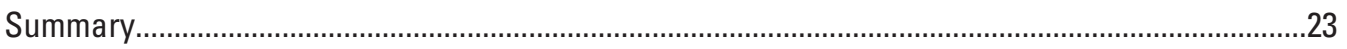

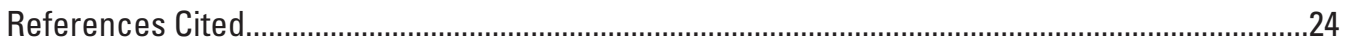

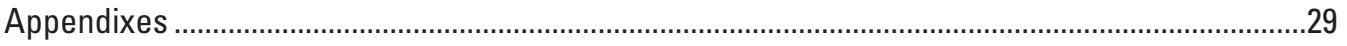

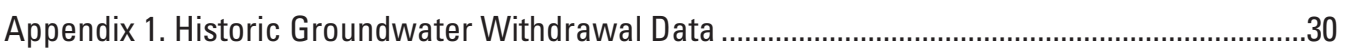

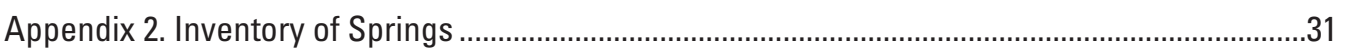

\section{Figures}

1 Physiography and location of Detrital, Hualapai, and Sacramento Valleys,

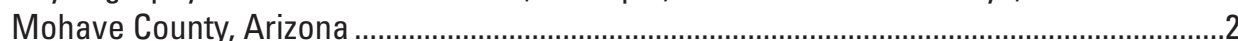

2 Generalized schematic cross-section of the Basin and Range subsurface geology characteristic of Detrital, Hualapai, and Sacramento Valleys, Mohave County, Arizona...

3 Subbasins within Detrital, Hualapai, and Sacramento Valleys, and corresponding maximum thicknesses of alluvium within each subbasin, Mohave County, Arizona............4

4 Reservoir-and-conveyance conceptual model used to describe water budgets for Detrital, Hualapai, and Sacramento Valleys, northwestern Arizona .....................................6

5 Schematic diagram showing general groundwater-recharge processes in Detrital, Hualapai, and Sacramento Valleys, Mohave County, Arizona .................................7

6 Location of water-withdrawal wells in Detrital, Hualapai, and Sacramento Valleys, Mohave County, Arizona. .9

$7 \quad$ Monthly groundwater sales data reported by four community water suppliers (CWS) in Hualapai and Sacramento Valleys, Mohave County, Arizona. 10

8 A, Cattails and bulrush growing in 75 acres of standing water in constructed wetlands at the City of Kingman wastewater treatment plant in Hualapai Valley, Mohave County, Arizona; B, Discharge of about 300,000 gallons per day of treated effluent into Holy Moses Wash from the City of Kingman wastewater treatment plant in Sacramento Valley, Mohave County, Arizona 


\begin{tabular}{|c|c|}
\hline 9 & $\begin{array}{l}\text { Water budget for Detrital Valley showing recent (2007-08) human-driven effects and } \\
\text { long-term (1940-2008) natural effects, Mohave County, Arizona....................................13 }\end{array}$ \\
\hline 10 & $\begin{array}{l}\text { Water budget for Hualapai Valley showing recent (2007-08) human-driven } \\
\text { effects and long-term (1940-2008) natural effects, Mohave County, Arizona }\end{array}$ \\
\hline 11 & $\begin{array}{l}\text { Water budget for Sacramento Valley showing recent (2007-08) human-driven } \\
\text { effects and long-term (1940-2008) natural effects, Mohave County, Arizona ..................17 }\end{array}$ \\
\hline 12 & $\begin{array}{l}\text { Stand of riparian vegetation dominated by saltcedar, looking upstream in } \\
\text { Sacramento Wash, Havasu National Wildlife Refuge, Mohave County, Arizona ..............19 }\end{array}$ \\
\hline 13 & $\begin{array}{l}\text { Groundwater withdrawals from Detrital, Hualapai, and Sacramento Valley } \\
\text { alluvial aquifers, 1940-2008, Mohave County, Arizona }\end{array}$ \\
\hline 14 & 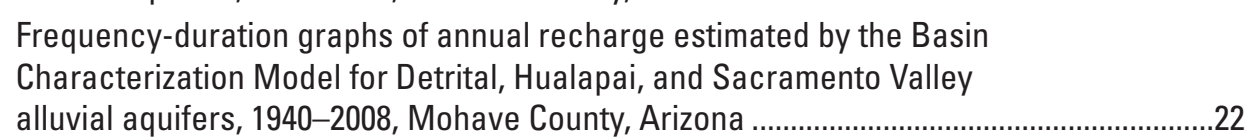 \\
\hline
\end{tabular}

\section{Tables}

1 Groundwater-budget values for Detrital Valley, Mohave County, Arizona ............................13

2 Groundwater-budget values for Hualapai Valley, Mohave County, Arizona ........................16

3 Groundwater-budget values for Sacramento Valley, Mohave County, Arizona ..................18

\section{Appendix}

\section{Figures}

2.1 Number of inventoried springs in Detrital, Hualapai, and Sacramento Valleys, Mohave County, Arizona

\section{Tables}

1.1 Annual groundwater withdrawals for Detrital, Hualapai, and Sacramento Valleys, 1940-2008, Mohave County, Arizona

2.1 Inventory of upland springs, identified by visual inspection of U.S. Geological Survey 1:24,000 topographic map sheets, Mohave County, Arizona.........32

2.2 Inventory of springs near the southern shoreline of Lake Mead, Mohave County, Arizona 


\section{Conversion Factors}

Inch/Pound to SI

\begin{tabular}{|c|c|c|}
\hline Multiply & By & To obtain \\
\hline \multicolumn{3}{|c|}{ Length } \\
\hline inch (in.) & 2.54 & centimeter $(\mathrm{cm})$ \\
\hline inch (in.) & 25.4 & millimeter $(\mathrm{mm})$ \\
\hline foot $(\mathrm{ft})$ & 0.3048 & meter $(\mathrm{m})$ \\
\hline mile (mi) & 1.609 & kilometer (km) \\
\hline \multicolumn{3}{|l|}{ Area } \\
\hline square mile $\left(\mathrm{mi}^{2}\right)$ & 259.0 & hectare (ha) \\
\hline square mile $\left(\mathrm{mi}^{2}\right)$ & 2.590 & square kilometer $\left(\mathrm{km}^{2}\right)$ \\
\hline \multicolumn{3}{|c|}{ Volume } \\
\hline gallon (gal) & 3.785 & liter $(\mathrm{L})$ \\
\hline gallon (gal) & 0.003785 & cubic meter $\left(\mathrm{m}^{3}\right)$ \\
\hline gallon (gal) & 3.785 & cubic decimeter $\left(\mathrm{dm}^{3}\right)$ \\
\hline million gallons (Mgal) & 3,785 & cubic meter $\left(\mathrm{m}^{3}\right)$ \\
\hline cubic foot $\left(\mathrm{ft}^{3}\right)$ & 28.32 & cubic decimeter $\left(\mathrm{dm}^{3}\right)$ \\
\hline cubic foot $\left(\mathrm{ft}^{3}\right)$ & 0.02832 & cubic meter $\left(\mathrm{m}^{3}\right)$ \\
\hline acre-foot (acre-ft) & 1,233 & cubic meter $\left(\mathrm{m}^{3}\right)$ \\
\hline acre-foot (acre-ft) & 0.001233 & cubic hectometer $\left(\mathrm{hm}^{3}\right)$ \\
\hline \multicolumn{3}{|c|}{ Flow rate } \\
\hline acre-foot per year (acre-ft/yr) & 1,233 & cubic meter per year $\left(\mathrm{m}^{3} / \mathrm{yr}\right)$ \\
\hline acre-foot per year (acre-ft/yr) & 0.001233 & cubic hectometer per year $\left(\mathrm{hm}^{3} / \mathrm{yr}\right)$ \\
\hline cubic foot per second $\left(\mathrm{ft}^{3} / \mathrm{s}\right)$ & 0.02832 & cubic meter per second $\left(\mathrm{m}^{3} / \mathrm{s}\right)$ \\
\hline gallon per minute (gal/min) & 0.06309 & liter per second $(\mathrm{L} / \mathrm{s})$ \\
\hline gallon per day (gal/d) & 0.003785 & cubic meter per day $\left(\mathrm{m}^{3} / \mathrm{d}\right)$ \\
\hline million gallons per day (Mgal/d) & 0.04381 & cubic meter per second $\left(\mathrm{m}^{3} / \mathrm{s}\right)$ \\
\hline inch per year (in/yr) & 25.4 & millimeter per year $(\mathrm{mm} / \mathrm{yr})$ \\
\hline
\end{tabular}

- Temperature in degrees Fahrenheit $\left({ }^{\circ} \mathrm{F}\right)$ may be converted to degrees Celsius $\left({ }^{\circ} \mathrm{C}\right)$ as follows: ${ }^{\circ} \mathrm{C}=\left({ }^{\circ} \mathrm{F}-32\right) / 1.8$

- Vertical coordinate information is referenced to the insert datum name (and abbreviation) here for instance, "North American Vertical Datum of 1988 (NAVD 88)."

- Horizontal coordinate information is referenced to the insert datum name (and abbreviation) here for instance, "North American Datum of 1983 (NAD 83)."

- Altitude, as used in this report, refers to distance above the vertical datum. 


\title{
Groundwater Budgets for Detrital, Hualapai, and Sacramento Valleys, Mohave County, Arizona, 2007-08
}

\author{
By Bradley D. Garner and Margot Truini
}

\section{Abstract}

The United States Geological Survey, in cooperation with the Arizona Department of Water Resources, initiated an investigation of the hydrogeology and water resources of Detrital, Hualapai, and Sacramento Valleys in northwestern Arizona in 2005, and this report is part of that investigation. Water budgets were developed for Detrital, Hualapai, and Sacramento Valleys to provide a generalized understanding of the groundwater systems in this rural area that has shown some evidence of human-induced water-level declines. The valleys are within the Basin and Range physiographic province and consist of thick sequences of permeable alluvial sediment deposited into basins bounded by relatively less permeable igneous and metamorphic rocks. Long-term natural recharge rates (1940-2008) for the alluvial aquifers were estimated to be 1,400 acre-feet per year (acre-ft/yr) for Detrital Valley, 5,700 acre-ft/yr for Hualapai Valley, and 6,000 acre-ft/yr for Sacramento Valley. Natural discharge rates were assumed to be equal to natural recharge rates, on the basis of the assumption that all groundwater withdrawals to date have obtained water from groundwater storage. Groundwater withdrawals (2007-08) for the alluvial aquifers were less than 300 acre-ft/yr for Detrital Valley, about 9,800 acre-ft/yr for Hualapai Valley, and about 4,500 acre-ft/yr for Sacramento Valley. Incidental recharge from leaking water-supply pipes, septic systems, and wastewater-treatment plants accounted for about 35 percent of total recharge (2007-08) across the study area. Natural recharge and discharge values in this study were 24-50 percent higher than values in most previously published studies. Water budgets present a spatially and temporally "lumped" view of water resources and incorporate many sources of uncertainty in this study area where only limited data presently are available.

\section{Introduction}

In northwestern Arizona, residents of Detrital, Hualapai, and Sacramento Valleys are contending with a growing population and limited water resources in an arid region. As in many rural areas throughout the American desert southwest, surfacewater resources are extremely limited (Jacobs and Stitzer, 2007), and groundwater is relied upon heavily to meet water demand. Effects of human groundwater use are evident in parts of Detrital, Hualapai, and Sacramento Valleys, with water-level declines of more than 130 feet (ft) associated with groundwater withdrawals (Anning and others, 2007). An increasing population (about 30 percent from 2000 to 2007) most likely will place further burdens on groundwater resources. Recently proposed developments for approximately 200,000 new houses and condominiums (K. Davidson, Mohave County Planning and Zoning Department, written commun., 2008) and new solar-power plants (Arizona Department of Water Resources, 2009b, p. 55; Hawkins, 2009) would be additional potential stresses on the groundwater systems.

The U.S. Geological Survey (USGS), in cooperation with the Arizona Department of Water Resources (ADWR), initiated a hydrologic investigation of Detrital, Hualapai, and Sacramento Valleys in 2005 as part of the Rural Watershed Initiative (RWI; Anning and others, 2006), a program created by the State of Arizona and managed by ADWR to develop an improved understanding of rural water resources. As a part of this investigation, water budgets have been created for Detrital, Hualapai, and Sacramento Valleys and are presented in this report. Water budgets are used to answer fundamental hydrologic questions, such as how much groundwater exists, how much is entering an aquifer, and how much is exiting. Water budgets invariably are simplifications and contain uncertainty, but can be excellent tools for generalized, first-order understanding and management of complex hydrologic systems (Healy and others, 2007).

\section{Purpose and Scope}

The purpose of this report is to present annual water budgets for each of Detrital, Hualapai, and Sacramento Valleys. Even small water-budget components with high uncertainty are identified and quantified where possible. The water budgets are "lumped" both spatially and temporally, meaning that single sets of numbers represent average combined effects for large areas and time spans. Although there is some discussion about spatial and temporal variability, the focus generally is on basin-wide conditions. The report concludes with a discussion of findings common to all three valleys, including uncertainty and limitations. 
Water budgets in this report represent average conditions as of 2007-08, and therefore, they do not represent predevelopment or steady-state conditions. Groundwater withdrawals, incidental recharge, and changes in groundwater storage are calculated as average 2007-08 conditions. Natural recharge and discharge, however, are calculated as long-term averages for 1940-2008 because interannual variability of recharge is large in the study area, and the large volume of the alluvial aquifers can be thought of as averaging out this year-over-year variability.

Water budgets in this report are developed with respect to the alluvial groundwater aquifers in Detrital, Hualapai, and Sacramento Valleys. Surface and anthropogenic processes are considered only insofar as they aid in quantifying water entering and exiting the alluvial aquifers. Infrequent, storm-driven streamflow that can flow out of the valleys is not quantified and is beyond the scope of this report. As discussed throughout this report, a key assumption is that groundwater withdrawals to date have not yet had an effect on natural recharge or natural discharge rates.

\section{Description of the Study Area}

The study area comprises Detrital, Hualapai, and Sacramento Valleys (fig. 1) within the Basin and Range physiographic province of North America (Fenneman, 1931). The region was shaped by Tertiary-period tectonism, wherein extensional faulting created horsts and grabens across a broad expanse of pre-existing (primarily metamorphic and igneous) rocks (Beard and others, in press; Fenneman, 1931). Thick sequences of alluvial fill, eroded from topographically high horst areas, were deposited into graben-formed basins beginning 13-16 million years ago (fig. 2). The sediment in these alluvial basins ranges in size from clays to boulders, with coarser grained material along basin margins and streambeds. Fine-grained material and evaporites generally are more prevalent in the basin centers. The thickness of alluvial fill is smallest near basin margins and reaches thicknesses of more than $14,000 \mathrm{ft}$ in the center of Hualapai Valley (fig. 3). Permeability of alluvial fill varies by location and depth, but it generally is greatest at the basin margins and along stream channels and is smallest in basin centers.

Metamorphic and volcanic rock (hereafter, bedrock) define the margins and floors of the alluvial basins. The margins are topographically high

Figure 1. Physiography and location of Detrital, Hualapai, and Sacramento Valleys, Mohave County, Arizona.

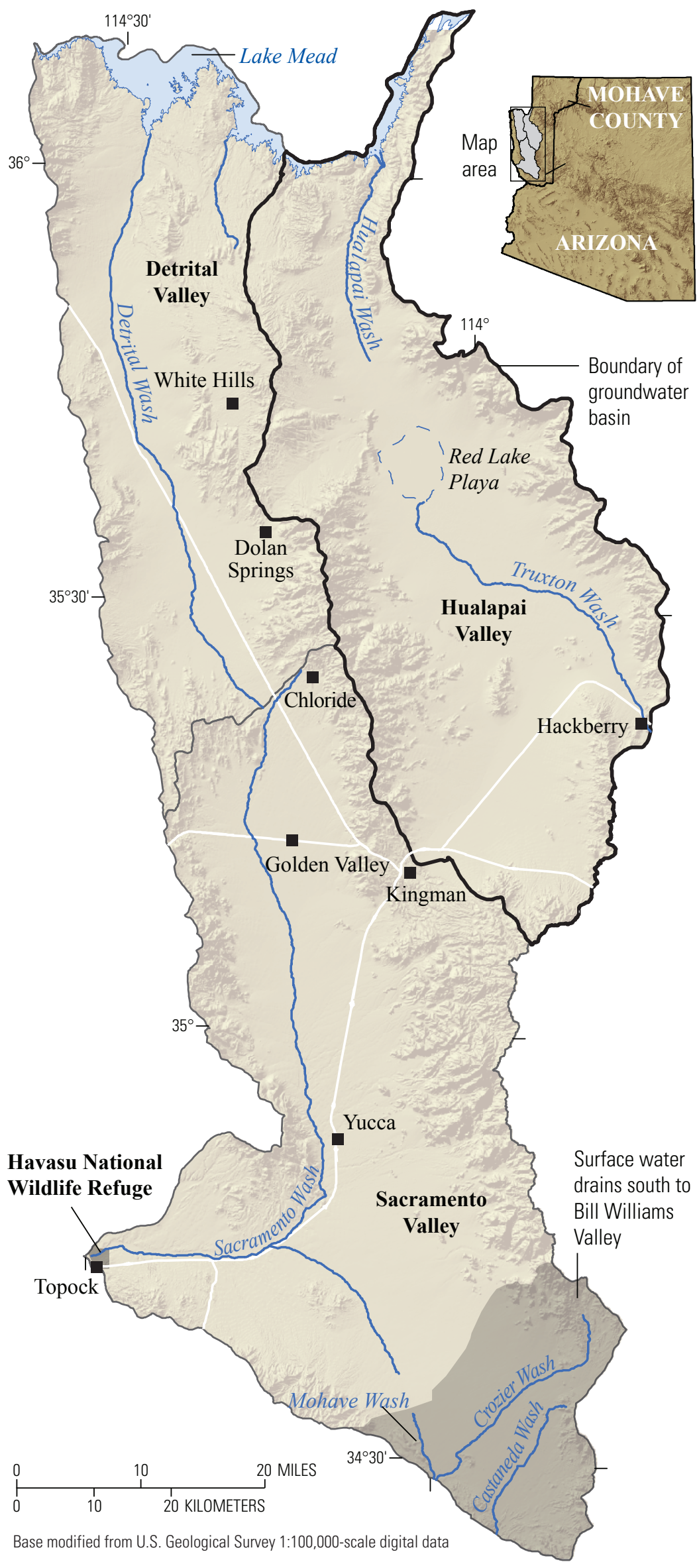


mountain ranges and hereafter are referred to as mountain blocks. Depth-to-bedrock analyses indicate that each valley within the study area consists of multiple hydrologically connected subbasins (Conway and Ivanich, 2007; Ivanich and Conway, 2007; Mason and others, 2007; fig. 3), each with distinctive hydrogeologic properties.

There are no major perennial stream reaches in the study area; the stream-channel network conveys water only briefly after large or intense rainfall or snowmelt events. Small springs in the mountain blocks (appendix 2) create short perennialstream reaches, but ultimately any such spring discharge either returns to the atmosphere through the process of evapotranspiration (ET) or re-enters the groundwater system as recharge. Springs in downgradient areas of Detrital and Hualapai Valleys near Lake Mead discharge water that may be associated with bank-storage effects from Lake Mead (Laney, 1979).

Detrital Valley has an area of about 900 square miles $\left(\mathrm{mi}^{2}\right)$, and its alluvial fill is as much as 5,000 ft thick; its largest ephemeral stream channel is Detrital Wash. Surface and groundwater flow is from south to north toward Lake Mead. Along its southern boundary, Detrital Valley is separated from Sacramento Valley by a topographic divide and shallow bedrock. There are three subbasins within Detrital Valley: Southern, Central, and Northern. As of the 2000 census, about 1,500 people lived in Detrital Valley, mostly in and around the community of Dolan Springs (U.S. Census Bureau, 2010a).

Hualapai Valley has an area of about $1,200 \mathrm{mi}^{2}$ and at its deepest point has almost twice the thickness of alluvial fill (more than 14,000 ft) as the other valleys in the study area. Truxton Wash is an ephemeral stream that enters Hualapai Valley from Truxton Canyon outside the study area and flows from southeast to northwest toward Red Lake Playa. This southern portion of Hualapai Valley is closed to surface-water drainage because of a topographic high north of Red Lake
Playa (Anderson, 1995). Groundwater in the valley flows generally from south to north toward Lake Mead. Red Lake is a vadose playa that is disconnected from the water table and, therefore, is not a groundwater discharge point (Anning and Konieczki, 2005). Hualapai Valley contains three subbasins: Kingman, Hualapai, and southern Gregg. Groundwater levels in some wells within the Kingman subbasin have declined more than $130 \mathrm{ft}$ (Anning and others, 2007) because of City of Kingman groundwater withdrawals from this subbasin that began in 1979 (G. Sedich, City of Kingman, oral commun., 2010). As of the 2000 census, about 30,000 people lived in Hualapai Valley, mostly within and around the City of Kingman (U.S. Census Bureau, 2010a).

Sacramento Valley has an area of about 1,600 $\mathrm{mi}^{2}$ and has about $8,500 \mathrm{ft}$ of alluvial fill at its deepest point. Sacramento Wash, an ephemeral stream, flows from north to south and then west toward the Colorado River. Diversions and impoundments of the Colorado River near Havasu National Wildlife Refuge (NWR) have altered the groundwater-flow system near the downgradient end of Sacramento Valley (Guay, 2001). There are three subbasins in Sacramento Valley: Chloride, Golden Valley, and Dutch Flat. Water levels were declining in the Golden Valley subbasin from the 1950s until about 1979, when City of Kingman began to withdraw most of its water from the Hualapai subbasin of Hualapai Valley instead of the Golden Valley subbasin (see appendix 1). About 15,000 people lived in Sacramento Valley as of the 2000 census, mostly in the City of Kingman and the Golden Valley subdivision (U.S. Census Bureau, 2010a).

The study area has an arid to semiarid climate. Average precipitation is 9.2 inches per year (in/yr), on the basis of data from 1940 through 2008 (Johnson and Taylor, 2010; see "The Basin Characterization Model" section). Precipitation is higher over mountainous areas (10.2 in/yr) than over valley floors

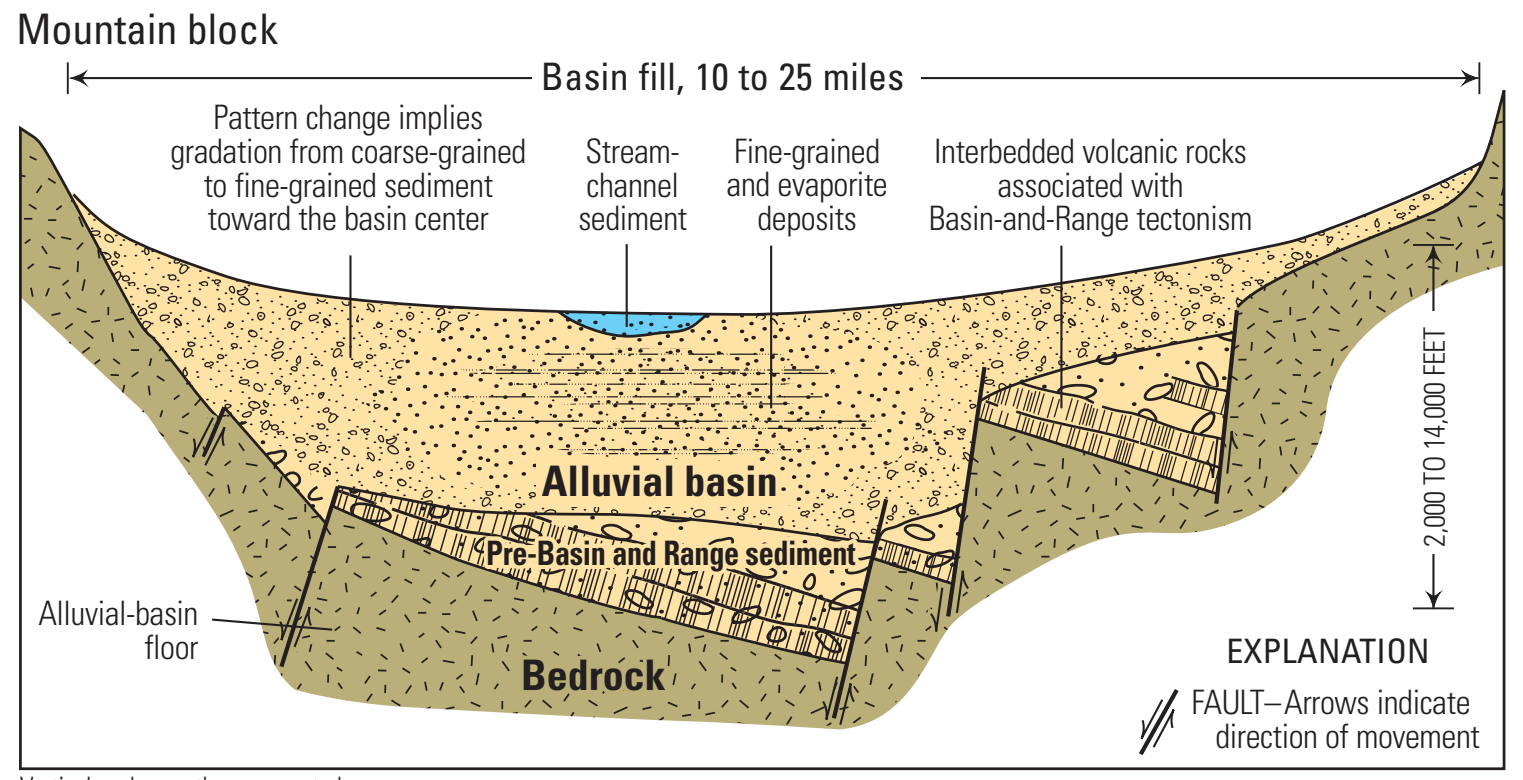

Vertical scale greatly exaggerated
Figure 2.

Generalized schematic crosssection of the Basin and Range subsurface geology characteristic of Detrital, Hualapai, and Sacramento Valleys, Mohave County, Arizona. Modified from Anderson (1995) and Beard and others (in press). 


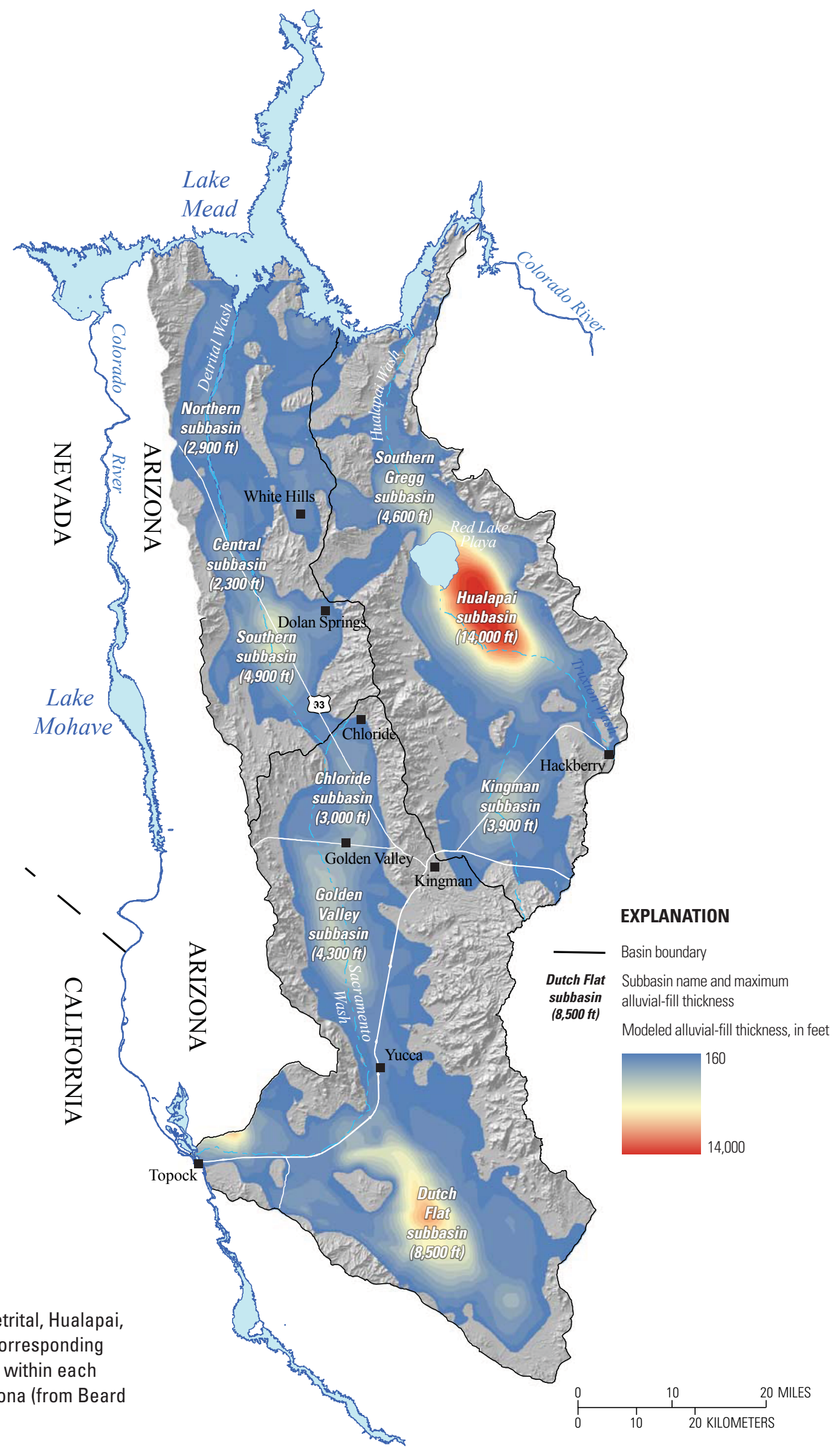

Figure 3. Subbasins within Detrital, Hualapai, and Sacramento Valleys, and corresponding maximum thickness of alluvium within each subbasin, Mohave County, Arizona (from Beard and others, in press). 
( $8.2 \mathrm{in} / \mathrm{yr}$ ) because of elevation effects on precipitation (Daly and others, 2002). Precipitation occurs primarily in two seasons. Winter precipitation (normally November through February) is characterized by slow, steady precipitation lasting several days, as well as by occasional winter storms that generate large precipitation events. Summer precipitation (normally June through September) follows a monsoonal pattern, where brief, intense thunderstorms produce large amounts of precipitation (often 1 inch or greater) in short periods over small areas. Little precipitation falls between April and June, although meltwater from winter snow and ice in mountain areas can produce recharge and runoff during these months. Weather disturbances associated with tropical storms occasionally enter the study area in the summer and fall and can produce considerable precipitation.

Maximum daily air temperatures range from 50 to $70^{\circ} \mathrm{F}$ in the winter and from 90 to $110^{\circ} \mathrm{F}$ in the summer (Anning and others, 2007). High summertime temperatures greatly increase potential ET, consequently decreasing the amount of precipitation that can become groundwater recharge during these months.

\section{Previous Investigations}

Two previous studies developed simplified water budgets for Detrital, Hualapai, and Sacramento Valleys. Gillespie and Bentley (1971) estimated surface-water runoff and groundwater-discharge rates for Hualapai and Sacramento Valleys. They also documented the occurrence of groundwater withdrawals and considered their impact on underflow between Hualapai Valley and Truxton Canyon outside of the study area. They did not evaluate incidental recharge. Freethey and Anderson (1986) presented predevelopment water budgets for all three valleys as part of the nationwide USGS Regional Aquifer-System Analysis (RASA) Program. Their values were considered to be semiquantitative only having been published using visual pie charts and arrows; however, the underlying quantitative values were available (AZ Water Science Center, U.S. Geological Survey, unpublished data) and, therefore, are shown for comparison in tables in this report.

Other studies contributed to an understanding of waterbudget components in the study area, but those studies did not develop complete water budgets. Metzger and Loeltz (1973) estimated Sacramento Valley groundwater discharge as part of their study of the Needles, California, area. Rascona (1991) also estimated groundwater discharge from Sacramento Valley. Historical groundwater-withdrawal data have been published for all three valleys (Anning and Duet, 1994; Babcock and others, 1972; Babcock and others, 1970; Babcock and others, 1969; Cox and others, 1968; Gillespie and Bentley, 1971; Hodges and others, 1967; Pfaff and Clay, 1979; Tadayon, 2005; White and others, 1965; White and others, 1964; White and others, 1963) and are summarized in appendix 1. Estimates of total groundwater storage for all three valleys were calculated by Conway and Ivanich (2007), Ivanich and Conway (2007), Mason and others (2007), and a USGS study being undertaken for the RWI (M. Truini, U.S. Geological Survey, written commun., 2011).

\section{Acknowledgment}

Don Bills, U.S. Geological Survey, provided assistance with data compilation and knowledge of the study area.

\section{Approach to Water-Budget Calculations}

A water budget is based on conservation-of-mass accounting of water flowing into and out of a system (Healy and others, 2007):

$$
I-O=\Delta S
$$

where $I$ is water input, $O$ is water output, and $\Delta S$ is change in water storage.

Although a water budget can be expressed entirely in equation form by expanding the terms in (1), lengthy and abstract equations can result. For this report, a reservoir-andconveyance conceptual model was used that emphasized diagrammatic presentation (fig. 4). In this model, natural and human processes cause water to move between reservoirs along conveyances. An imbalance between total water conveyed into and out of a reservoir produces changes in storage in that reservoir. The reservoirs identified for this report were atmosphere, mountain block, ephemeral stream, alluvial unsaturated zone, alluvial aquifer, and human infrastructure. Processes identified that moved water between reservoirs were precipitation, ET, runoff, infiltration, recharge, upland spring discharge, groundwater withdrawals, consumptive use, water-supply pipe leakage, underflow, streamflow into the valley, and discharge to Lake Mead or the Colorado River.

Conceptually, any reservoir can undergo storage change, but for the purposes of this report only storage in the alluvial aquifer reservoir (hereafter, groundwater storage) was considered. Total storage and year-over-year storage change in snow, ice, perennial streams, lakes, vegetation, human infrastructure, and the alluvial unsaturated zone were beyond the scope of this report.

Water-budget component values are reported in units of acre-feet per year (acre-ft/yr), except for total groundwater storage, which is reported in millions of acre-feet (maf). Annual data are reported in terms of calendar years. Values greater than 10,000 acre- $\mathrm{ft}$ are rounded to the nearest 1,000 acre- $\mathrm{ft}$, all others are rounded to the nearest 100 acre- $\mathrm{ft}$, and values below 300 acre-ft are censored (less than, or $<$ ), unless reported more accurately by another source. Because of rounding and censoring, some table columns may not sum to zero.

Water budgets in this report represent average 2007-08 conditions, except for natural recharge, which was calculated for 1940-2008. The goal was to develop a single set of numbers that reflect recent (2007-08) human effects on alluvial aquifers, placed in the context of long-term (1940-2008) natural conditions. To that end, the following assumptions were made:

- Natural recharge was unaffected by human activity during 1940-2008. This was considered reasonable because 
water tables in the study area are not near the land surface in recharge areas along mountain fronts and in alluvial streambeds (Anderson, 1995).

- Withdrawal rates in 2007-08 were not affected by unusually high or low precipitation amounts. This was considered reasonable, because withdrawals in 2007-08 are consistent with the overall increasing trend in withdrawals from 1940-2008 (see appendix 1).

- Average climatic conditions were the same prior to 1940. The period 1940-2008 includes multiple cycles of multiyear and decadal climate cycles known to exist in the southwestern United States (Pool, 2005). Longer scale climatic cycles and(or) human-driven climate change would not necessarily be represented by this period, and are beyond the scope of this report.

\section{Natural Recharge (1940-2008)}

Natural recharge to alluvial aquifers in the study area derives from precipitation that falls and infiltrates the ground and is not lost to ET or other processes. Also, some surface water and underflow enters Hualapai Valley from Truxton Canyon, a valley outside of the study area.

\section{The Basin Characterization Model}

The Basin Characterization Model (BCM; Flint and Flint, 2007b) was used to estimate natural recharge to the alluvial aquifers in the study area. The BCM is a physically based distributed model that calculates surface energy and surface mass flux in an 885- $\mathrm{ft}$ grid across the model domain. The model was developed for the entire southwestern United States; therefore, this report includes results only from a small portion of the model domain. Results from the model have been used in other hydrologic and water-balance studies (for example, Flint and Flint, 2007a; Heilweil and others, 2007; Tillman and others, 2011).

Natural recharge is a complex function of precipitation intensity, duration, magnitude, and temporal distribution, as well as geology, land-surface slope, and vegetative cover (Anderson, 1995). Inputs required for the BCM include topography, distributed precipitation and climate, and hydraulic properties of soil and surficial rocks. Precipitation and climate data were obtained from Parameter-elevation Regressions on Independent Slopes Model (PRISM) datasets from 1940-2008. PRISM datasets are modelderived, developed by extrapolating point measurements of precipitation at weather stations into a spatial grid by using statistical and human-expertise approaches (Daly and others, 2002; Johnson and Taylor, 2010). The number of precipitation stations available for use by PRISM was very limited within the study area compared to other areas of the United States, which increased uncertainty in precipitation estimates (Daly and others, 2008).

For each grid cell in the study area, a monthly volume of water was calculated and divided among three pathways: in-place recharge, runoff, and ET (fig. 5). In-place recharge is precipitation or meltwater that infiltrates and becomes groundwater recharge within the same grid cell in which it fell. Runoff is water remaining on the surface in a grid cell that could enter stream channels and eventually infiltrate through a channel streambed. Potential ET

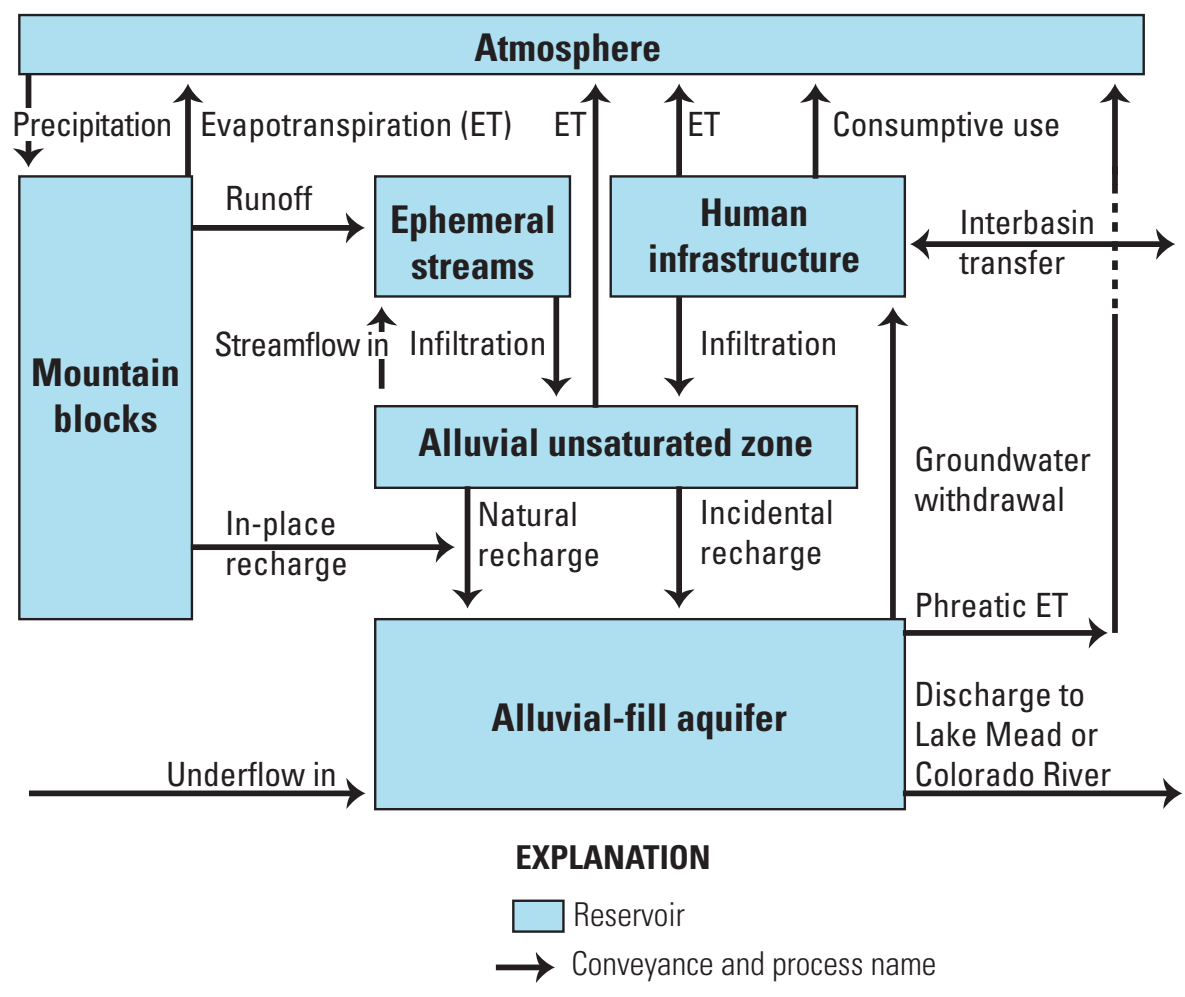

Figure 4. Reservoir-and-conveyance conceptual model used to describe water budgets for Detrital, Hualapai, and Sacramento Valleys, Mohave County, Arizona. Infiltration from the human-infrastructure reservoir includes septic tanks, wastewater-treatment plants, and leaking water-supply pipes. ET, evapotranspiration. 
is subtracted from the amount of water calculated as runoff. $\mathrm{BCM}$ is not a routing model; it only calculates the water that infiltrates or remains on the surface in each grid cell. Grid cells can accumulate and store water as snowpack and soil water in one month and release this water in subsequent months.

The BCM indicates that, as in other arid alluvial basins, high potential ET within the study area generally prevents recharge and runoff from alluvial valley floors (Heilweil and others, 2007; Moore, 2007; Phillips, 1994; Stewart-Deaker and others, 2007; Stonestrom and others, 2007). Even though valley floors produce no recharge or runoff according to the $\mathrm{BCM}$, runoff produced in mountain blocks flows ephemerally in stream channels that cross valley floors, and some of this runoff becomes recharge. In-place recharge from mountain blocks eventually either flows into alluvial aquifers through the subsurface, or reemerges from upland mountainblock springs.

\section{Calculation of Natural Recharge Using the Basin Characterization Model}

Annual natural recharge from precipitation was estimated by using outputs of the BCM from 1940 to 2008 with the equation:

$$
R=\left(R_{I}-Q_{u s}\right)+0.1\left(R O+Q_{u s}\right)
$$

where $R$ is natural recharge, $R_{I}$ is BCM-computed in-place recharge, $R O$ is BCM-computed runoff, $Q_{u s}$ is upland spring discharge, and 0.1 (10 percent) is a coefficient for how much runoff becomes recharge.

The assumption that 10 percent of runoff $(R O)$ becomes recharge was based on values from comparable areas summarized by Flint and Flint (2007b): 12-15 percent (Amargosa River, southern Nevada), 15-40 percent (Walnut Gulch, southeastern
Arizona), 10 percent (southern Mojave Desert, California), 10 percent (Death Valley, California), and 90 percent (middle Humboldt Basin, western Nevada). The study area for this report is most similar to the study from the Mojave Desert of California.

Discharge from springs in upland mountain-block areas $\left(Q_{u s}\right)$ was estimated by using an inventory of springs and spring-discharge measurements (appendix 2). $Q_{u s}$ was subtracted from $R_{I}$ and added to $R O$ under the assumption that upland springs represent a conversion of already accounted for in-place recharge into runoff.

\section{Natural Recharge from Upgradient Streamflow and Underflow}

Groundwater and surface water in Hualapai Valley are connected hydrologically to an area outside of the study area known as Truxton Canyon. Average streamflow (runoff) entering Hualapai Valley in Truxton Wash was estimated by using data from USGS gaging station 09404343 (1994-2009). Of this streamflow, 45 percent was assumed to recharge the alluvial aquifer, a value halfway between 10 percent (BCM runoff) and 80 percent (incidental recharge). This intermediate value was arbitrarily chosen because alluvial streambeds are efficient at recharging aquifers because they are underlain by coarser-grained material (D. Pool, U.S. Geological Survey, oral commun., 2010), yet some of the infiltrating water likely returns to the atmosphere through ET within and adjacent to the streambed.

There is also a subsurface hydrologic connection-and, therefore, a potential for underflow-between Hualapai Valley and the adjacent Truxton Canyon, and this was evaluated by using groundwater levels, well logs, and previous studies.

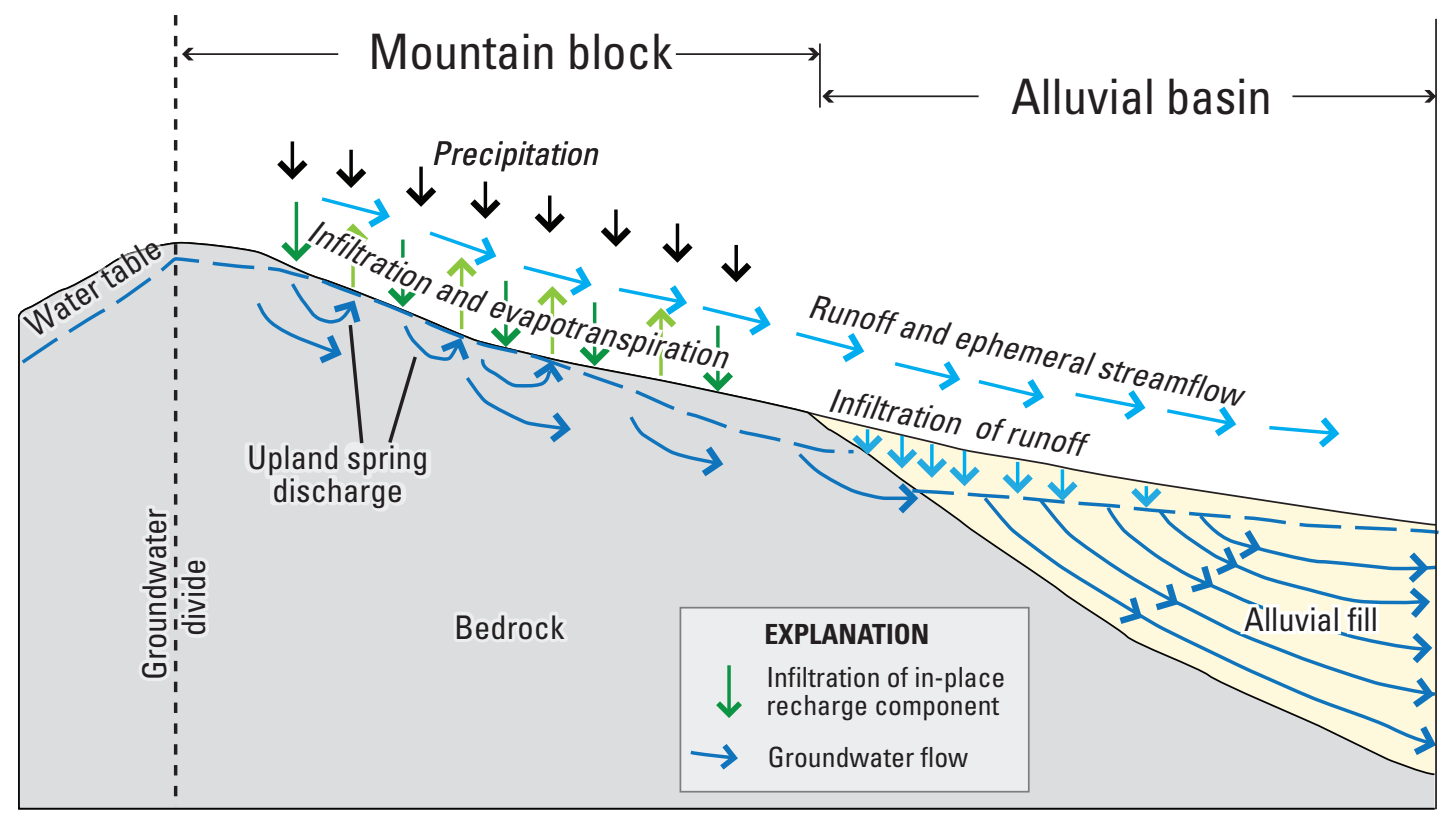

Figure 5. Schematic diagram showing general groundwaterrecharge processes in Detrital, Hualapai, and Sacramento Valleys, Mohave County, Arizona. Modified from Berger (2000). 


\section{Natural Discharge (1940-2008)}

Natural discharge occurs from Detrital, Hualapai, and Sacramento Valley alluvial aquifers primarily as discharge to Lake Mead or the Colorado River (Freethey and Anderson, 1986; Gillespie and Bentley, 1971). Some natural discharge can occur as ET, which includes transpiration by vegetation that uses groundwater directly (phreatic ET). Other natural-discharge pathways either are not present in the study area (for example, perennial streamflow), or are assumed to be either negligible or irrelevant for the purposes of a basin-scale water budget (for example, downward and lateral leakage through bedrock).

\section{Discharge to Lake Mead or the Colorado River}

Discharge to Lake Mead or the Colorado River is the primary means by which groundwater discharges from the alluvial aquifers within the study area. This component was assumed to be equal to natural recharge minus any phreatic ET, reflecting a key assumption discussed further in the "Effects of Groundwater Withdrawals" section.

Previous studies, particularly Freethey and Anderson (1986), have referred to this component as underflow. Although perhaps a reasonable term on a regional scale, underflow was considered a misnomer for this report; strictly speaking, the Colorado River is a perennial stream that gains groundwater discharge from the valleys.

Alternative approaches to calculating this discharge component were investigated, but ultimately not used. Springs along the perimeter of Lake Mead suggested a possible means of directly estimating natural discharge, but were not used for water-budget calculations (see the "Springs Near Lake Mead" section). Darcy's law of groundwater flow was evaluated for applicability, but input parameters (hydraulic conductivity, gradient, and cross-sectional area) had too much uncertainty to produce a helpful, constraining result.

\section{Phreatic Evapotranspiration}

Values for phreatic ET were obtained from Tillman and others (2011), a regional water-availability study of southwest alluvial basins that used greenness indexes from spectroradiometric satellite data to estimate phreatic ET along stream channels and in areas of woody and herbaceous plants. Tillman and others determined general water availability over an area much larger than Detrital, Hualapai, and Sacramento Valleys; therefore, their basin-scale results were evaluated for inclusion in the water budgets of this report using depth-to-water maps and field vegetation surveys.

\section{Groundwater Withdrawals}

Groundwater wells throughout the study area are sources of water for domestic, municipal, industrial, and other water uses (fig. 6). More than 3,300 wells were registered with ADWR within the study area as of June 2009 (Arizona
Department of Water Resources, 2009a), but withdrawal data generally are not available on a per-well basis. Some organizations report total annual withdrawals of their actively pumped wells to State agencies, while the remaining wells generally are owned by individuals who are not required to report their withdrawals. It is unlikely that all 3,300 wells were in active use as of 2007-08; figure 6, therefore, is only a general indication of the location of withdrawals within the study area.

Annual withdrawal data (2007 and 2008) for the City of Kingman, community water suppliers (CWSs), and industrial facilities were compiled using methods described in Tadayon (2005). Data were obtained from reports submitted to the Arizona Corporation Commission (ACC; Arizona Corporation Commission, 2010), and questionable values were verified with telephone calls to water suppliers, where possible. These reported values were based on flowmeter measurements from 2007 and 2008, and values in this report are an average of these two years. Some water withdrawn by the City of Kingman from Hualapai Valley is transferred to Sacramento Valley to satisfy water demand (G. Sedich, City of Kingman, oral commun., 2010). The amount of water transferred was calculated by assuming a uniform rate of water use by City of Kingman residents, and dividing groundwater-withdrawal values between the valleys on the basis of City of Kingman population distribution between the two valleys (U.S. Census Bureau, 2010a).

Groundwater withdrawals by the self-supplied domestic (SSD) population were estimated indirectly by using population data, as these residents own small private wells with withdrawals that are neither measured nor reported. The SSD population was inferred by subtracting the number of people served by City of Kingman and CWSs in a valley from the estimated 2007 population of that valley. This inferred SSD population was multiplied by a per-capita water use of 133 gallons per person per day (Tadayon, 2005). The population served by City of Kingman municipal utility in each valley was assumed to be the census-reported "urban" population in that valley (no City of Kingman residents live in Detrital Valley). The population served by CWSs in each valley was estimated by dividing total annual CWS water deliveries by a per-capita water use of 133 gallons per person per day.

Study-area population estimates were obtained from Year 2000 U.S. Census data (U.S. Census Bureau, 2010a) that were adjusted to estimated 2007 levels by increasing the population 29 percent uniformly across the study area. This percentage was calculated on the basis of 2007 population estimates for City of Kingman as well as Mohave County (U.S. Census Bureau, 2010b).

\section{Incidental Recharge}

Water use by humans can result in recharge when some of the nonconsumptively used water returns to the groundwater system. In a populated arid basin, this incidental recharge can be a substantial proportion of total recharge. Although no direct measurements of incidental recharge are available for the study area, potential pathways of incidental recharge (fig. 4) were investigated. Water is 


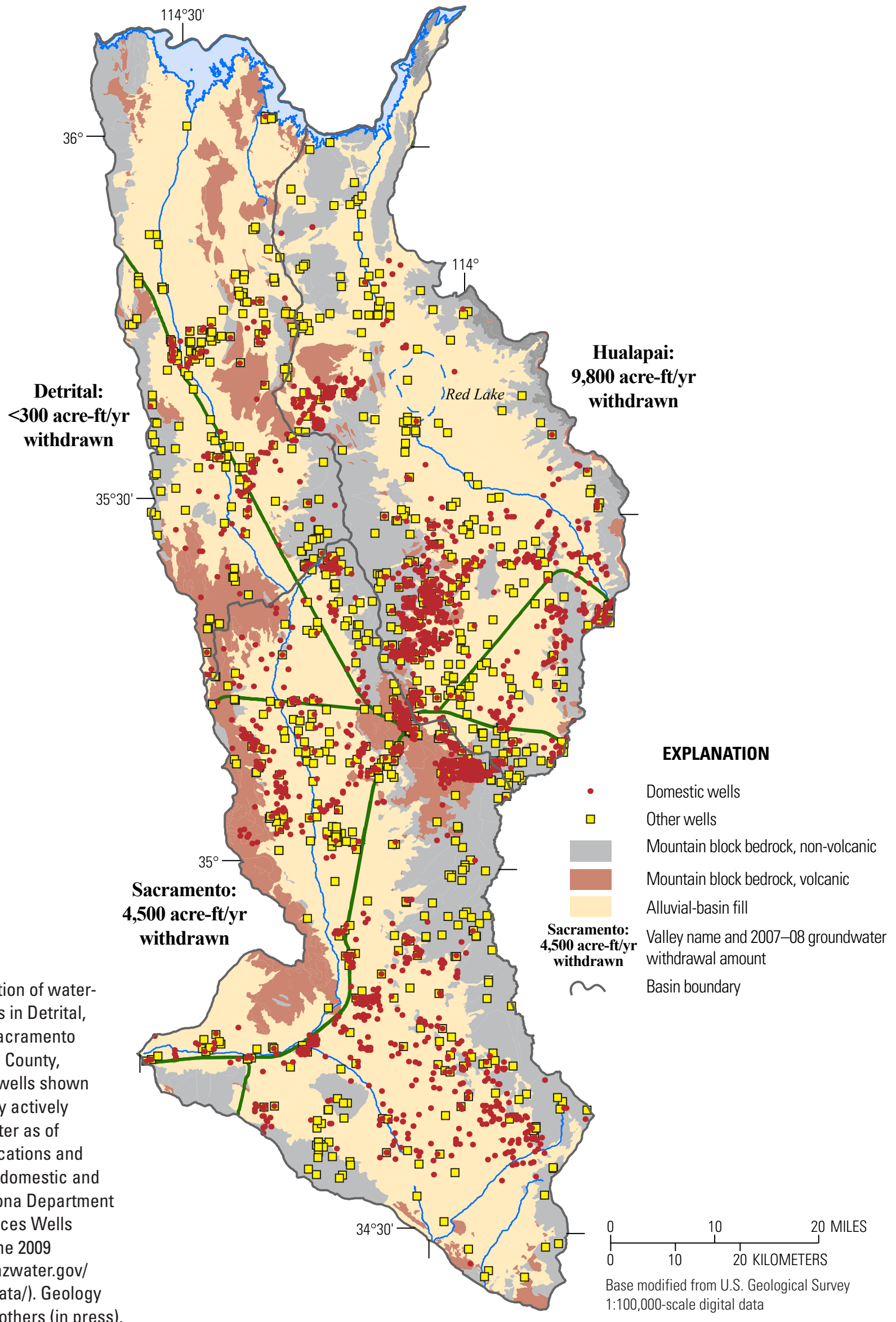

Figure 6. Location of waterwithdrawal wells in Detrital, Hualapai, and Sacramento Valleys, Mohave County, Arizona. Not all wells shown were necessarily actively withdrawing water as of 2007-08. Well locations and water-use type (domestic and other) from Arizona Department of Water Resources Wells 55 database, June 2009 (https://gisweb.azwater.gov/ waterresourcedata/). Geology from Beard and others (in press). 
delivered to customers through water-supply pipes that invariably leak. Some water delivered to customers is returned to the atmosphere through consumptive use. The remaining unconsumed water (wastewater) discharges to septic or sewer systems, and some of it eventually reenters the groundwater system as recharge.

\section{Water-Supply Pipe Leakage}

The annual percentage of water that leaked from water-supply pipes (unmetered loss) was calculated as the difference between volume of groundwater withdrawn and volume of water billed as being delivered to customers. Some activities, such as firefighting and filling of municipal pools, contribute to unmetered loss, but were considered negligible. For City of Kingman municipal utility, 2007-08 data indicate average annual unmetered losses of 7 percent. For CWSs, average annual unmetered losses were about 9 percent, on the basis of data reported to the ACC that were screened for common data errors. These percentages fall within ranges observed worldwide ( 5 to more than 60 percent; Sharp and Garcia-Fresca, 2003), and are similar to the 10-percent value observed in water systems that have efficient water-main repair and replacement procedures (Sharp and Garcia-Fresca, 2003). Industrial and SSD water-supply pipes were assumed to have no leaks as there were no data to indicate otherwise, and their typically short lengths might be more actively monitored and maintained than municipal water-supply pipes. Water transferred from Hualapai to Sacramento Valley was assumed to leak from pipes only in Sacramento Valley.

Of all unmetered-loss water, 80 percent was assumed to become recharge. The rationale for this assumption was that a leaking water pipe buried several feet below land surface behaves similarly to a septic-system drain field, and 80 percent was the amount of septic-system water assumed to become recharge. This is likely an oversimplification, but there have been no studies of recharge from leaking water-supply pipes in this or comparable areas.

\section{Consumptive Use}

Some water delivered to customers for domestic use is returned to the atmosphere through consumptive use. Within the study area, consumptive-use activities consist primarily of summertime activities, such as yard watering, gardening, and use of evaporative-cooling systems. An annual consumptive-use coefficient of 28 percent was calculated for domestic water uses within the study area by using the winter base-rate method (LaTour, 1991; Shaffer, 2009). This method assumes that (1) all increased summertime domestic water use is associated with 100 percent consumptive-use activities, (2) consumptive use is minimal in the winter, and (3) conconsumptive use remains constant throughout the year. Monthly groundwater-withdrawal data were compiled from CWSs and screened for common data errors (for example, obvious hundred- or thousand-fold errors caused by incorrect reporting units). The coefficient was calculated as the mean winter-withdrawal rate for each year (December through February) subtracted from the annual-mean withdrawal rate for the entire year, divided by the annualmean withdrawal rate (fig. 7). Consumptive-use coefficients calculated for 2007 and 2008 for 15 CWSs were between 18 and 43 percent, with a mean of 28 percent.

A consumptive-use coefficient of 100 percent was assumed for industrial water uses, indicating that all water supplied to industrial customers was expected to return to the atmosphere. This was considered reasonable because more than 90 percent of industrial water use in the study area was for thermoelectric power generation, a process that ultimately evaporates all water either through cooling towers or evaporation ponds (B. Henderson, Griffith Energy LLC, oral commun., 2010).
Figure 7. Monthly groundwater sales data reported by four community water suppliers (CWS) in Hualapai and Sacramento Valleys, Mohave County, Arizona. The figure is annotated to indicate how the winter base-rate method can be used to estimate consumptive use. Additional CWS data are available, but they are omitted here to improve readability.

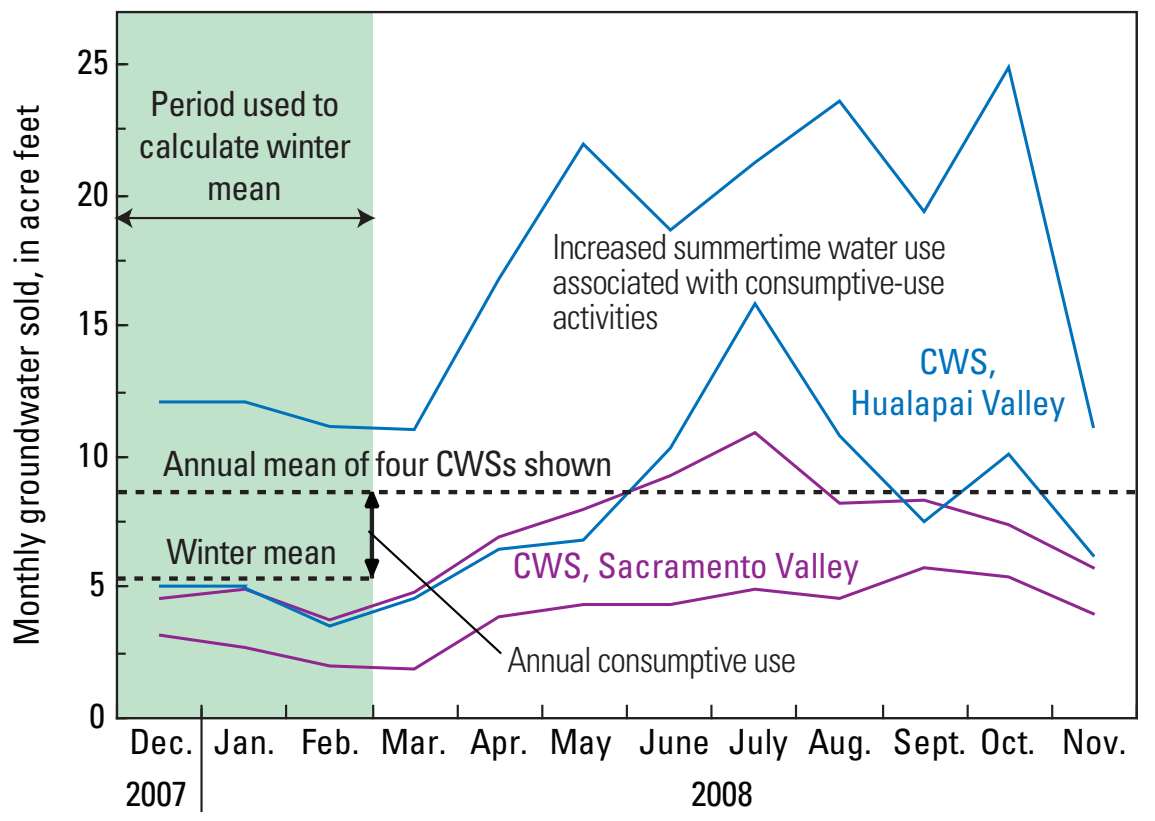




\section{Recharge from Septic Systems}

Most residents in the study area discharge their wastewater (that is, water not consumptively used) to septic systems, which in turn discharge to the unsaturated zone through drain fields. After a review of studies in comparable areas, 80 percent of this drain-field discharge was assumed to become recharge. Studies in Arizona's San Pedro Valley used values of 100 percent (Arizona Department of Water Resources, 2005 ) and 60 percent (K. Lansey, University of Arizona, written commun., 2010). A study of California's Joshua Tree groundwater basin assumed a value of 100 percent (Nishikawa and others, 2004), although the initial wetting front may take decades to reach the water table (Flint and Ellett, 2004).

The 20 percent of drain-field discharge that does not become recharge is accounted for in three ways. First, some initial amount of drain-field discharge is incorporated permanently into a very dry unsaturated zone. Second, some desert plants likely use some of this discharge water, even if it is discharged below the commonly assumed base of the root zone. Finally, upward gradients for water vapor can exist in arid unsaturated zones (Stonestrom and others, 2007; Walvoord and others, 2004), although fluxes through this path usually are much smaller than recharge values (de Vries and Simmers, 2002).

\section{Recharge from Wastewater-Treatment Plants}

About 40 percent of City of Kingman residents discharge their wastewater to sewer systems that lead to two wastewatertreatment plants (WWTPs). The other 60 percent of City of Kingman residents discharge wastewater to septic systems; this proportion was determined by comparing the volume of unconsumed water calculated as being produced in City of Kingman with the volume of water reported as being treated by the WWTPs.

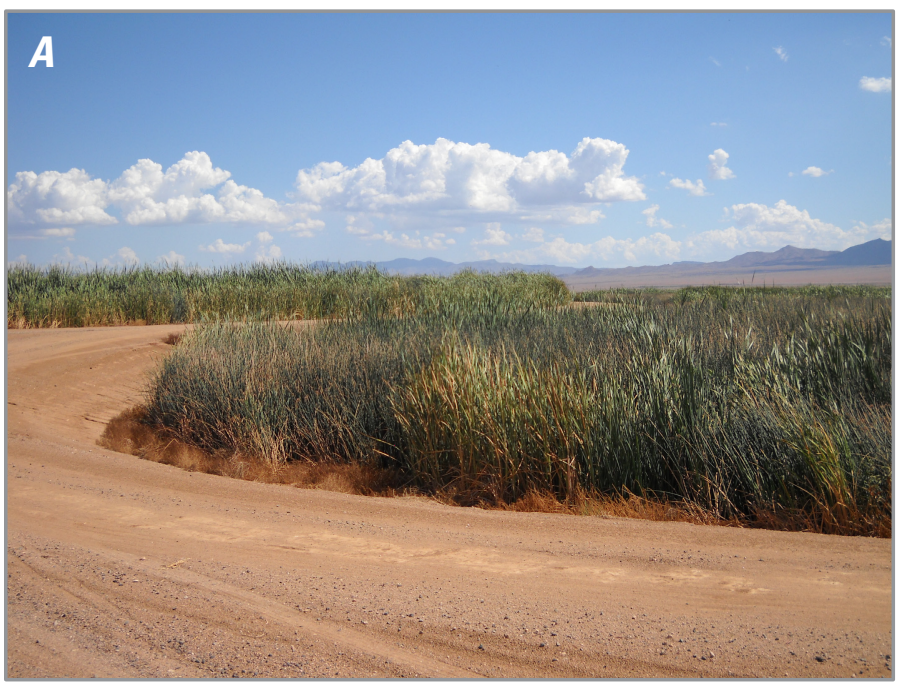

At City of Kingman's two WWTPs, treated effluent is discharged into stands of dense vegetation (fig. 8). Treated effluent from the WWTP in Hualapai Valley is discharged to constructed wetlands, and the WWTP in Sacramento Valley discharges treated effluent to a stream channel filled with vegetation. One-hundred percent of treated effluent likely returns to the atmosphere through ET during June, July, and August as no surface-water flow exits these vegetation stands during these months (J. Corwin, City of Kingman, oral commun., 2010), and infiltration is unlikely because of clogging layers (Treese and others, 2009) or soil compaction. Fifty percent of effluent is assumed to return to the atmosphere through ET during April, May, September, and October; ET is assumed to be 10 percent of the treated effluent during all other months. After weighing each of these percentages $(100,50$, and 10$)$ by the proportional amount of water treated in each month, about 52 percent of treated wastewater was estimated to return to the atmosphere through ET on an annual basis, leaving the remaining 48 percent to infiltrate and potentially become recharge.

Of the 48 percent of treated effluent assumed to infiltrate annually, 80 percent is assumed to recharge the alluvial aquifer. This is the same percentage assumed for discharge from septic systems, and the rationales are similar. This water recharges either through streambed infiltration (Sacramento Valley WWTP), or through rapid infiltration basins (Hualapai Valley WWTP).

\section{Groundwater Storage and Storage Changes}

Within the study area, most groundwater storage is within the intergranular pore spaces of the alluvial aquifers of each valley. Fractures within bedrock (particularly volcanic rocks) also store small but sometimes important volumes of water. The volume of water stored in bedrock is assumed to be negligible compared to the large amount stored in the alluvial

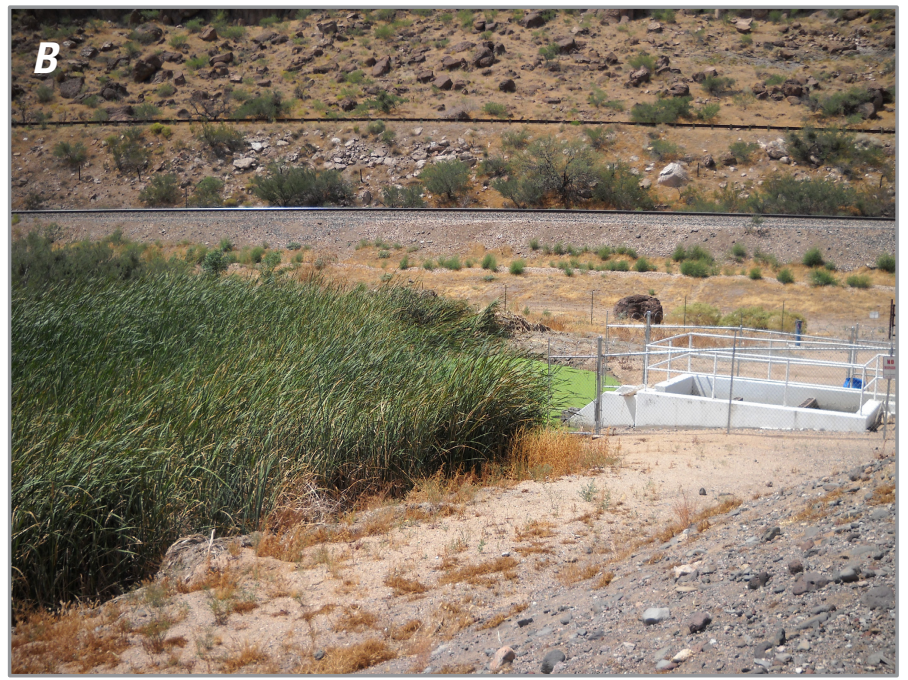

Figure 8. $A$, Cattails and bulrush growing in 75 acres of standing water in constructed wetlands at the City of City of Kingman wastewater-treatment plant in Hualapai Valley, Mohave County, Arizona; $B$, Discharge of about 300,000 gallons per day of treated effluent into Holy Moses Wash from the City of City of Kingman wastewater-treatment plant in Sacramento Valley, Mohave County, Arizona. 
aquifers, and therefore, groundwater-storage estimates in this report do not include storage in bedrock.

Estimates of total groundwater storage for the alluvial aquifers of Detrital, Hualapai, and Sacramento Valleys to a depth of 1,300 below land surface (bls) have been calculated for a separate USGS study for the RWI (M. Truini, U. S. Geological Survey, written commun., 2011) and are shown in this report. They were based on 2006 water-table elevations and include any storage reductions that have been caused by withdrawals up through 2005 .

Groundwater-storage changes in the alluvial aquifers of Detrital, Hualapai, and Sacramento Valleys were calculated by subtracting output water-budget components from input components. Inputs comprised natural recharge and incidental recharge. Outputs comprised natural discharge (phreatic ET and discharge to Lake Mead or the Colorado River) and groundwater withdrawals (fig. 4).

Because natural discharge is assumed to equal natural recharge, storage changes represent only the imbalance between groundwater withdrawals and incidental recharge. One implication of this assumption is that groundwater withdrawals are assumed to derive all water from depletion of groundwater storage and none by depletion of natural discharge or streamflow. This key assumption is discussed further in the "Effects of Groundwater Withdrawals" section.

A method for estimating storage change by using gravity measurements (Pool and Eychaner, 1995) was considered but not used, because there were not enough long-term data available from gravity-measurement stations in the study area. Changes between consecutive measurements in 2007 and 2008 were within measurement uncertainty (R. Carruth, U.S. Geological Survey, oral commun., 2010), except for one station in City of Kingman where a statistically significant decrease was consistent with water-level declines observed in that area.

\section{Detrital Valley Water Budget}

\section{Natural Recharge}

Natural recharge to the Detrital Valley alluvial aquifer is estimated to be 1,400 acre-ft/yr (fig. 9; table 1), on the basis of BCM calculations. Detrital Valley receives an average of 360,000 acre-ft/yr (7.6 in/yr) of precipitation. Of this total precipitation, 232,000 acre-ft/yr falls on the valley floor, and 128,000 acre-ft/yr falls on mountain blocks. All valley-floor precipitation returns to the atmosphere through ET, and about 1,400 acre-ft/yr (1.1 percent) of mountain-block precipitation eventually becomes recharge. This recharge comprises 1,200 acre-ft/yr of in-place recharge and $200 \mathrm{acre-ft} / \mathrm{yr}$ of recharge resulting from runoff.

\section{Natural Discharge}

Natural discharge from the Detrital Valley alluvial aquifer is estimated to be 1,400 acre-ft/yr (fig. 9). This value was assumed to be the same as estimated natural recharge, reflecting a key assumption discussed further in the "Effects of Groundwater Withdrawals" section. Although most natural discharge occurs as groundwater discharge to Lake Mead, a small amount may occur as phreatic ET.

Tillman and others (2011) estimated that between 1,200 and 2,200 acre-ft/yr of groundwater discharges from the Detrital Valley alluvial aquifer through phreatic ET, but a spatial analysis of their results indicates that this range is unlikely to be accurate for Detrital Valley. Tillman and others estimated that most phreatic ET occurs along the shoreline of Lake Mead, but groundwater near the shoreline could well be bank-storage water, not water from the Detrital Valley alluvial aquifer. Tillman and others also estimated a small amount of phreatic ET occurring within and along the ephemeral Detrital Wash; however, groundwater levels from wells near Detrital Wash indicated a 32- to 870-ft unsaturated zone (Anning and others, 2007), suggesting that phreatic ET in this area is minimal. Thus, for the purposes of this water budget, phreatic ET was considered to be a negligible component of natural discharge.

Evidence of groundwater discharge or paleodischarge was found along the western side of Temple Bar Road in northern Detrital Valley, where small tufa mounds with distinctive vegetation appear to follow a linear strike (L.S. Beard, U.S. Geological Survey, oral commun., 2010). Tufa, a type of carbonate deposit, can indicate the discharge of mineralized groundwater. However, in the American southwest, tufa deposits most likely "indicate a change from a wetter to a drier climate" (Sweeting, 1973, p. 110), not a present-day groundwater discharge site. Distinctive vegetation on these mounds could be caused by differing soil chemistry and permeability rather than availability of shallow groundwater. Consequently, any present-day discharge at these mounds, considered unlikely in any case, is deemed negligible.

\section{Springs near Lake Mead}

Springs were identified near the shoreline of Lake Mead that could be discharge points for groundwater from the Detrital Valley alluvial aquifer (see appendix 2). Because of the bank-storage effect of Lake Mead, however, care must be taken in interpreting this spring discharge and its possible sources. This section discusses the possibility of bank-storage water being the source of discharge for springs located below the maximum water-surface elevation of Lake Mead (1,229 ft above sea level).

As Lake Mead's water-surface elevation rises, water infiltrates from the reservoir into permeable unsaturated sediments along the shoreline. When the water-surface elevation falls, water that had infiltrated into the sediments discharges back to the lake (Bales and Laney, 1992). This discharge can occur as diffuse seepage along canyon 
Table 1. Groundwater-budget values for Detrital Valley, Mohave County, Arizona; includes values from previous studies for comparison.

[acre-ft/yr, acre-feet per year; maf, millions of acre-feet; <, less than; ET, evapotranspiration]

\begin{tabular}{|c|c|c|c|c|c|}
\hline \multirow[b]{2}{*}{ Water-budget component } & \multicolumn{2}{|c|}{ This study } & \multicolumn{3}{|c|}{ Other studies } \\
\hline & $\begin{array}{l}\text { Inflow to aquifer } \\
\text { (acre-ft/yr) }\end{array}$ & $\begin{array}{l}\text { Outflow from aquifer } \\
\text { (acre-ft/yr) }\end{array}$ & $\begin{array}{c}\text { Freethey and } \\
\text { Anderson (1986) } \\
\text { (acre-ft/yr) }\end{array}$ & $\begin{array}{c}\text { Tillman and } \\
\text { others (2011) } \\
\text { (acre-ft/yr) }\end{array}$ & $\begin{array}{c}\text { Other } \\
\text { (see footnote }) \\
\text { (acre-ft/yr) }\end{array}$ \\
\hline Natural recharge & 1,400 & & 700 & 22,000 & \\
\hline Mountain-block recharge & 1,200 & & & & \\
\hline Natural discharge & & 1,400 & 700 & & \\
\hline to Lake Mead & & 1,400 & & & \\
\hline Phreatic ET & & $<300$ & $<1,000$ & 2,000 & \\
\hline Groundwater withdrawals & & $<300$ & & & ${ }^{3}<300$ \\
\hline Incidental recharge & $<300$ & & & & \\
\hline Totals & 1,600 & 1,600 & & & \\
\hline
\end{tabular}

${ }^{1}$ Predevelopment. Values obtained from unpublished tabular data. Plates in report show only qualitative ranges of values.

${ }^{2}$ Based on re-running Freethey and Anderson (1986) models with revised precipitation data.

${ }^{3}$ Tadayon (2005), value as of year 2000.

${ }^{4}$ Mason and others (2007).

Detrital Valley Water Budget

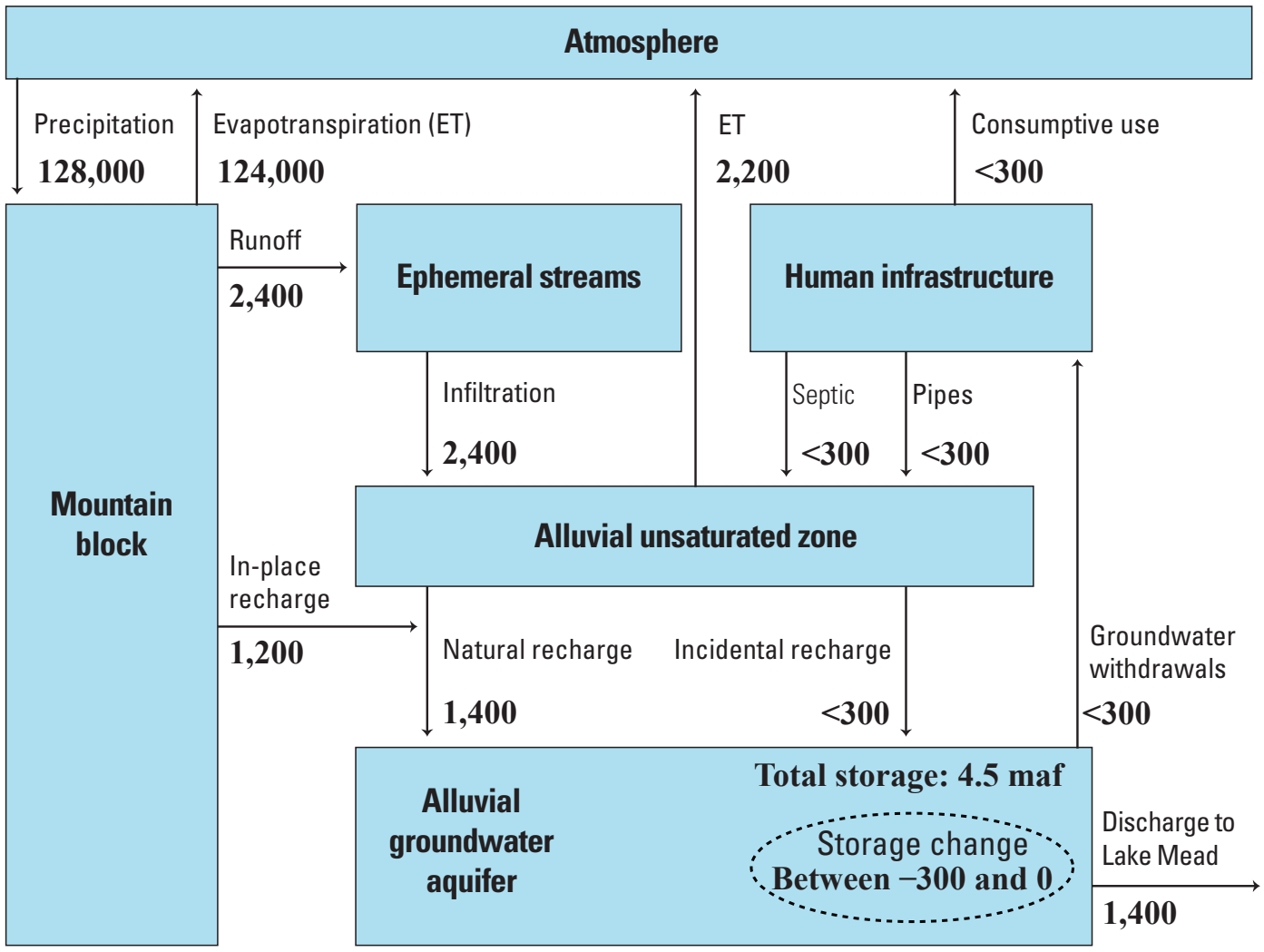

Figure 9. Water budget for Detrital Valley showing recent (2007-08) human-driven effects and long-term (1940-2008) natural effects, Mohave County, Arizona. All units are acre-feet per year, unless otherwise indicated; maf, millions of acre-feet. 
walls (Laney, 1979), or as focused discharge from highpermeability sediments. Bank-storage effects probably extend no more than half a mile from the lake's edge (Bales and Laney, 1992; Mcbride and Pfannkuch, 1975) and have been observed in wells adjacent to Lake Mead where water levels rise and fall in response to Lake Mead water-surface elevation changes (Laney, 1979).

Monkey Cove Spring, located at 1,150 ft above sea level, is the largest identified spring below Lake Mead's maximum water-surface elevation; its discharge has been measured to be as much as 1,700 gallons per minute (gal/min). From 1971 to April 2003, this spring was submerged by as much as 75 feet of water from Lake Mead. From April 2003 through 2009, the spring was above the reservoir water level and discharged water visibly. The spring's discharge was $1,350 \mathrm{gal} / \mathrm{min}$ in February 2008, but only $380 \mathrm{gal} / \mathrm{min}$ in May 2009. Many factors can contribute to such large changes in measured discharge, and future studies could investigate this further. Because the source of water for Monkey Cove and other similar springs was not clear, flow rates of these springs were not used to estimate natural discharge.

\section{Groundwater Withdrawals}

Groundwater withdrawals from the Detrital Valley alluvial aquifer (2007-08) were less than $300 \mathrm{acre-ft/yr.}$ This total is reasonable considering that about 1,700 people lived in the valley in 2007 and there were no major industrial or agricultural water uses. Water use was evenly divided between the SSD population (700 people) and the population served by CWSs (1,000 people). CWS water use occurred in and around the community of Dolan Springs.

\section{Incidental Recharge}

Incidental recharge to the Detrital Valley alluvial aquifer (2007-08) was less than 300 acre-ft/yr, which reflects the low rate of water use in the valley. Individual components of incidental recharge considered by this report (water-supply pipes, septic systems, and WWTPs) were each less than $100 \mathrm{acre}-\mathrm{ft} / \mathrm{yr}$. There are no WWTPs in Detrital Valley.

\section{Groundwater Storage}

Groundwater storage in the Detrital Valley alluvial aquifer was estimated to be decreasing during 2007-08, but at less than 300 acre-ft/yr. From 1940 through 2008, between 3,400 and 15,000 acre-ft of water have been withdrawn. Total groundwater storage to a depth of $1,300 \mathrm{ft}$ bls is estimated to be $4.5 \mathrm{maf}$ (M. Truini, U.S. Geological Survey, written commun., 2011).

\section{Hualapai Valley Water Budget}

\section{Natural Recharge}

Natural recharge to the Hualapai Valley alluvial aquifer is estimated to be 5,700 acre-ft/yr (fig. 10; table 2), on the basis of BCM calculations. Hualapai Valley receives an average of $610,000 \mathrm{acre}-\mathrm{ft} / \mathrm{yr}(9.4 \mathrm{in} / \mathrm{yr})$ of precipitation. Of this total precipitation, 384,000 acre- $\mathrm{ft} / \mathrm{yr}$ falls on the valley floor, and 226,000 acre-ft/yr falls on mountain blocks. All valley-floor precipitation returns to the atmosphere through ET, and about $4,800 \mathrm{acre}-\mathrm{ft} / \mathrm{yr}$ ( 2.1 percent) of mountain-block precipitation eventually becomes recharge. Total natural recharge comprises 4,400 acre-ft/yr of in-place recharge from mountain blocks, $400 \mathrm{acre}-\mathrm{ft} / \mathrm{yr}$ of recharge resulting from mountain-block runoff, 600 acre-ft/yr from streamflow in Truxton Wash, and 300 acre- $\mathrm{ft} / \mathrm{yr}$ as underflow beneath Truxton Wash.

Estimates of underflow into Hualapai Valley beneath Truxton Wash are complicated by large changes in water-table elevation since the 1950s. Under predevelopment conditions, an estimated 300 acre-ft/yr entered Hualapai Valley as underflow on the basis of water-table maps (Freethey and Anderson, 1986). During the 1960s, however, groundwater gradients appeared reverse, resulting in about 1,000 acre-ft/yr flowing out of Hualapai Valley (Gillespie and Bentley, 1971). By the early 1980s, groundwater levels had risen and underflow might have once again flowed into Hualapai Valley, although limited data make this unclear. Well B-23-13 19DCB exemplifies this pattern: in 1944, the depth-to-water was $53 \mathrm{ft}$; in 1973 , it was $111 \mathrm{ft}$; in 1980, it was $61 \mathrm{ft}$; and in 2001, it was $98 \mathrm{ft}$. For the purposes of this report, with the understanding that the value is highly uncertain, underflow into Hualapai Valley was estimated to be $300 \mathrm{acre}-\mathrm{ft} / \mathrm{yr}$ - the same value reported by Freethey and Anderson (1986).

\section{Natural Discharge}

Natural discharge from the Hualapai Valley alluvial aquifer is estimated to be 5,700 acre-ft/yr. This value was assumed to be the same as estimated natural recharge, reflecting a key assumption discussed further in the "Effects of Groundwater Withdrawals" section. Although most natural discharge occurs as groundwater discharge to Lake Mead, some unquantified amount could occur as phreatic ET.

Tillman and others (2011) estimated that between 1,800 and 3,200 acre-ft/yr of groundwater discharges from the Hualapai Valley alluvial aquifer through phreatic ET, but that value was not used in this water budget. The rationale was the same as that used for Detrital Valley (see the "Natural Discharge" subsection within the "Detrital Valley Water Budget" section). 


\section{Groundwater Withdrawals}

Groundwater withdrawals from the Hualapai Valley alluvial aquifer (2007-08) were about 9,800 acre-ft/yr, of which 1,200 acre-ft/yr was delivered to Sacramento Valley through an interbasin transfer. Of the 8,600 acre-ft/yr used in Hualapai Valley, essentially all was for municipal and domestic uses. The City of Kingman municipal utility served about 84 percent of all residents $(33,000$ people) in Hualapai Valley and, in so doing, used about 7,600 acre-ft/yr of water. CWSs pumped about 500 acre-ft/yr, serving about 7 percent of the valley population $(2,800$ people). About 9 percent of the valley population ( 3,500 people) is estimated to be SSD, withdrawing about $500 \mathrm{acre}-\mathrm{ft} / \mathrm{yr}$.

About 2 acre- $\mathrm{ft} / \mathrm{yr}$ was reported to be withdrawn for industrial use in Hualapai Valley (2007-08). This value is considered negligible in the context of this report's water budgets.

\section{Incidental Recharge}

About 4,200 acre-ft/yr of water (2007-08) recharged the Hualapai Valley alluvial aquifer as a result of human infrastructure and water use. About 500 acre-ft/yr of this was from leaks in water-supply lines, 3,000 acre-ft/yr from septic-system drain fields, and 800 acre- $\mathrm{ft} / \mathrm{yr}$ from the rapid infiltration basins of the Hualapai WWTP. Although about 80 percent of septic-system discharge recharged the aquifer, only 38 percent of effluent treated by the Hualapai Valley WWTP did so. This difference is due to high summertime ET from the WWTP wetlands.

The Hualapai WWTP reported treating about 2,000 acre-ft/yr of effluent, but 5,100 acre-ft/yr of effluent is estimated to be produced by residents of City of Kingman. The discrepancy is caused by about 60 percent of City of Kingman residents in Hualapai Valley receiving municipal water, but discharging their effluent to septic systems. This 60 -percent value is similar to the 50-percent value estimated by the City of Kingman municipal utility (J. Corwin, City of Kingman, oral commun., 2010).

\section{Hualapai Valley Water Budget}

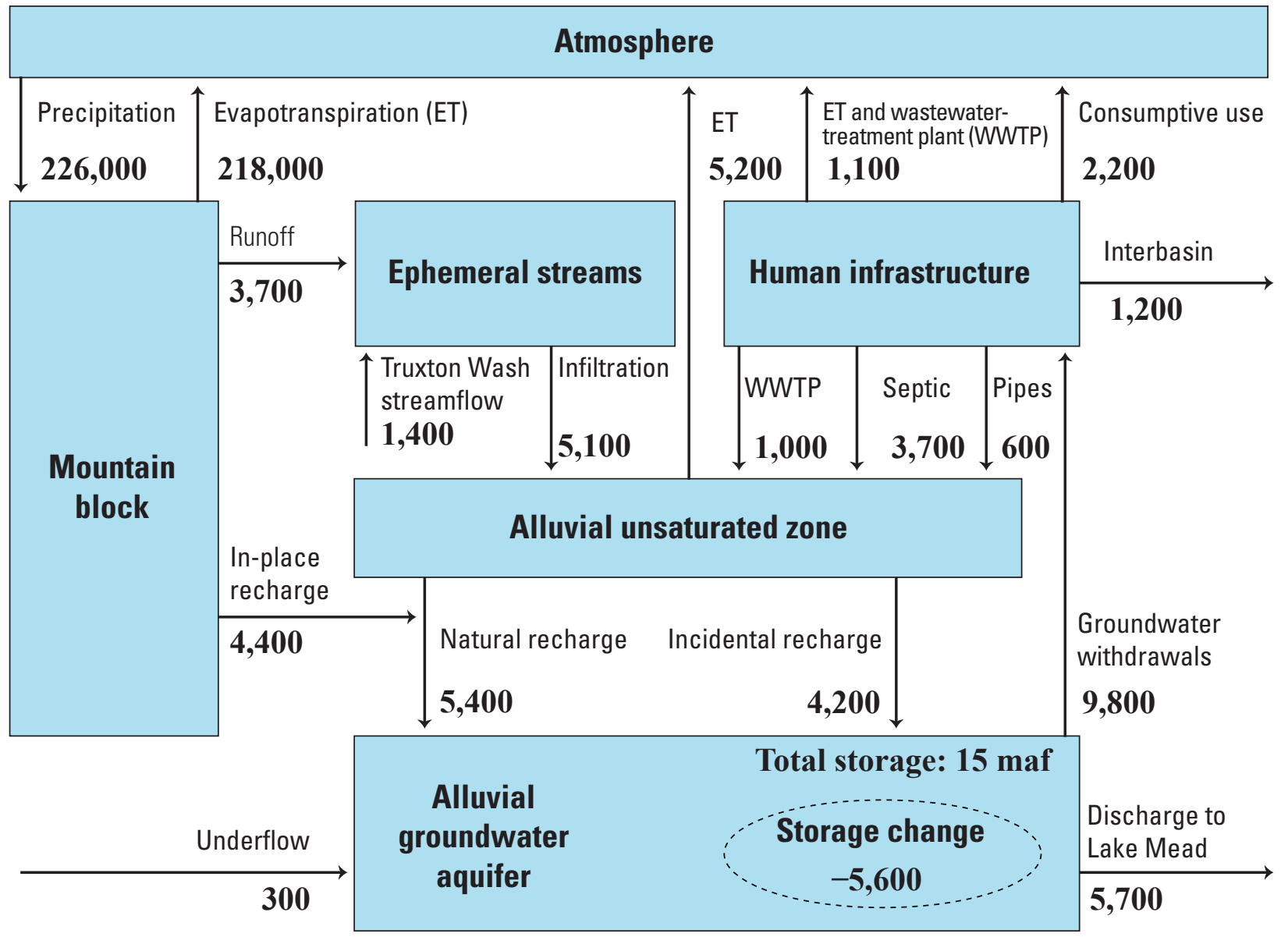

Figure 10. Water budget for Hualapai Valley showing recent (2007-08) human-driven effects and long-term (1940-2008) natural effects, Mohave County, Arizona. All units are acre-feet per year, unless otherwise indicated; maf, millions of acre-feet. 
Table 2. Groundwater-budget values for Hualapai Valley, Mohave County, Arizona; includes values from previous studies for comparison.

[acre-ft/yr, acre-feet per year; maf, millions of acre-feet; <, less than; WWTP, wastewater-treatment plant; CWS, community water supplier; SSD, self-supplied domestic; ET, evapotranspiration]

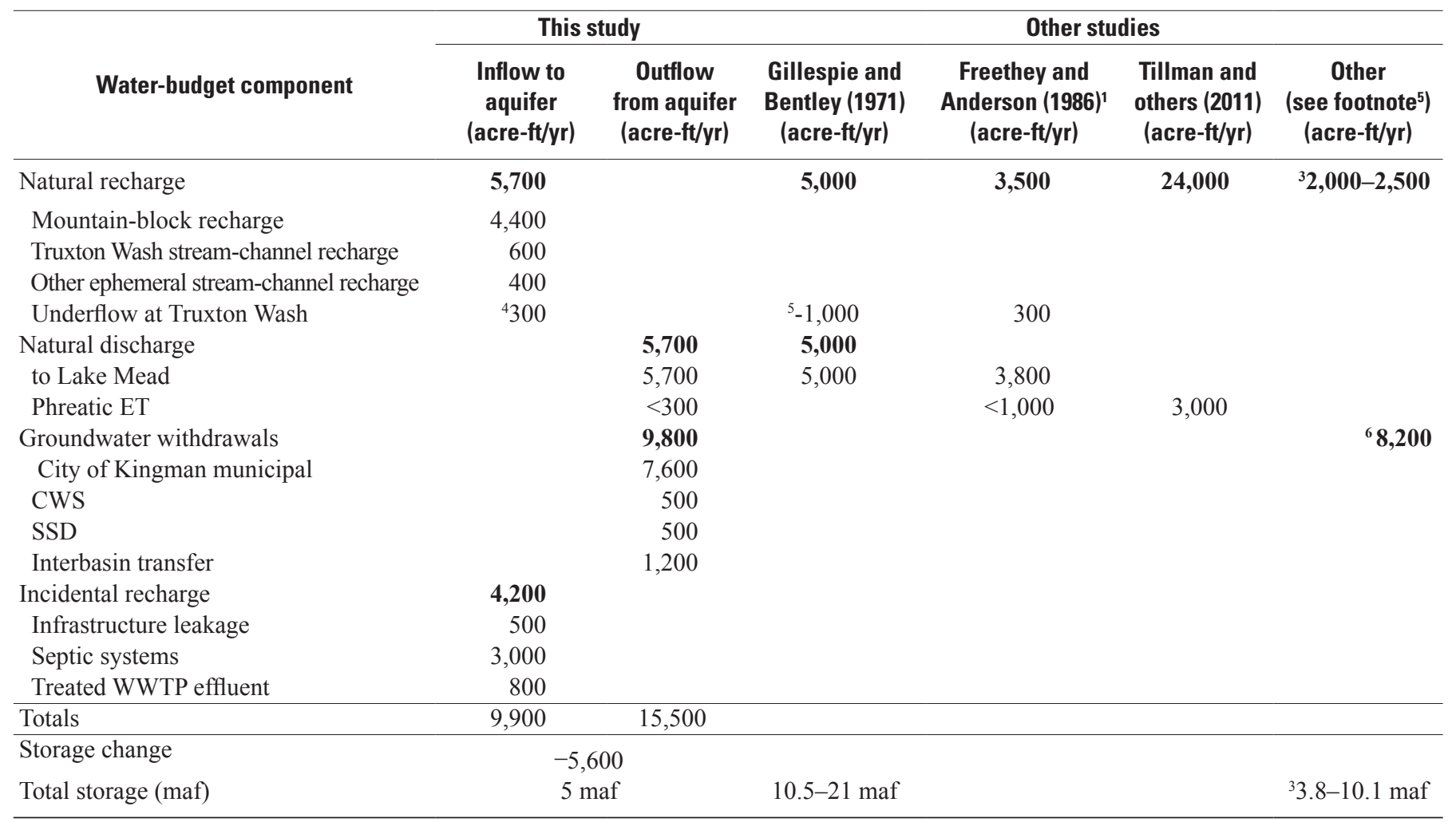

${ }^{1}$ Predevelopment. Values obtained from unpublished tabular data. Plates in report show only qualitative ranges of values.

${ }^{2}$ Based on re-running Freethey and Anderson (1986) models with revised precipitation data.

${ }^{3}$ Ivanich and Conway (2007).

${ }^{4}$ From Freethey and Anderson (1986) pre-development conditions, as there are insufficient data to calcualte a current-condition value.

${ }^{5}$ Negative indicates basin outflow, rather than inflow, because of large Truxton Canyon pumping withdrawals in the 1960s.

${ }^{6}$ Tadayon (2005), value as of year 2000.

\section{Groundwater Storage}

Groundwater storage was estimated to be decreasing at about 5,600 acre-ft/yr during 2007-08. While 9,800 acre-ft/yr was withdrawn by pumping, about $4,200 \mathrm{acre}-\mathrm{ft} / \mathrm{yr}$ returned to the aquifer as incidental recharge-about 43 percent of withdrawals. One factor to consider in evaluating this number, however, is that 1,200 acre-ft/yr of water left Hualapai Valley through an interbasin transfer; excluding this interbasin-transfer water, the ratio of incidental recharge to withdrawals is about 50 percent. Total groundwater storage to a depth of $1,300 \mathrm{ft}$ bls is estimated to be 15 maf, reflecting 2006 water-level conditions (M. Truini, U.S. Geological Survey, written commun., 2011).

\section{Sacramento Valley Water Budget}

\section{Natural Recharge}

Natural recharge to the Sacramento Valley alluvial aquifer is estimated to be 6,000 acre-ft/yr (fig. 11; table 3), on the basis of BCM calculations. Sacramento Valley receives an average of 770,000 acre-ft/yr (9.1 in/yr) of precipitation. Of this total precipitation, 440,000 acre- $\mathrm{ft} / \mathrm{yr}$ falls on the valley floor, and 340,000 acre-ft/yr falls on mountain blocks. All valley-floor precipitation returns to the atmosphere through ET, and about 6,000 acre-ft/yr (1.8 percent) of mountain-block precipitation becomes recharge. This recharge comprises 
5,100 acre-ft/yr of in-place recharge and 800 acre-ft/yr of recharge resulting from runoff.

The stream-channel network in southernmost Sacramento Valley drains southward to Bill Williams Valley, even though groundwater in the area flows northward and remains in Sacramento Valley (Anning and others, 2007; fig. 1). Some surfacewater runoff, therefore, exits the study area through Mohave and Castaneda Washes - perhaps as much as 700 acre- $\mathrm{ft} / \mathrm{yr}$, as indicated by the BCM. However, even if all of this runoff exited the study area (unlikely, as some probably would infiltrate), under the assumption that 10 percent of BCM runoff becomes recharge, total recharge would reduced by only 70 acre-ft/yr (about 1 percent). Because of uncertainty in these quantities, for the purposes of this report, streamflow to Bill Williams Valley is not included in water-budget calculations. Streamflow monitoring on Mohave and Castaneda Washes would aid future studies in better understanding the hydrology of this area.

\section{Natural Discharge}

Natural discharge from the Sacramento Valley alluvial aquifer is estimated to be $6,000 \mathrm{acre}-\mathrm{ft} / \mathrm{yr}$. This value is assumed to be the same as estimated natural recharge, reflecting a key assumption discussed further in the "Effects of Groundwater Withdrawals" section. Natural discharge occurs mostly as groundwater discharge to the Colorado River, but some could occur through phreatic ET near Havasu NWR. As discussed in the preceding section, amounts of ephemeral streamflow to Bill Williams Valley are uncertain and were not included in this total natural discharge value.

Tillman and others (2011) estimated that between 5,800 and 10,000 acre-ft/yr of groundwater discharges from the Sacramento Valley alluvial aquifer through phreatic ET, but spatial analysis and field verification of their data suggest a more reasonable value would be 2,000 acre-ft/yr. Their analysis indicated between

Sacramento Valley Water Budget

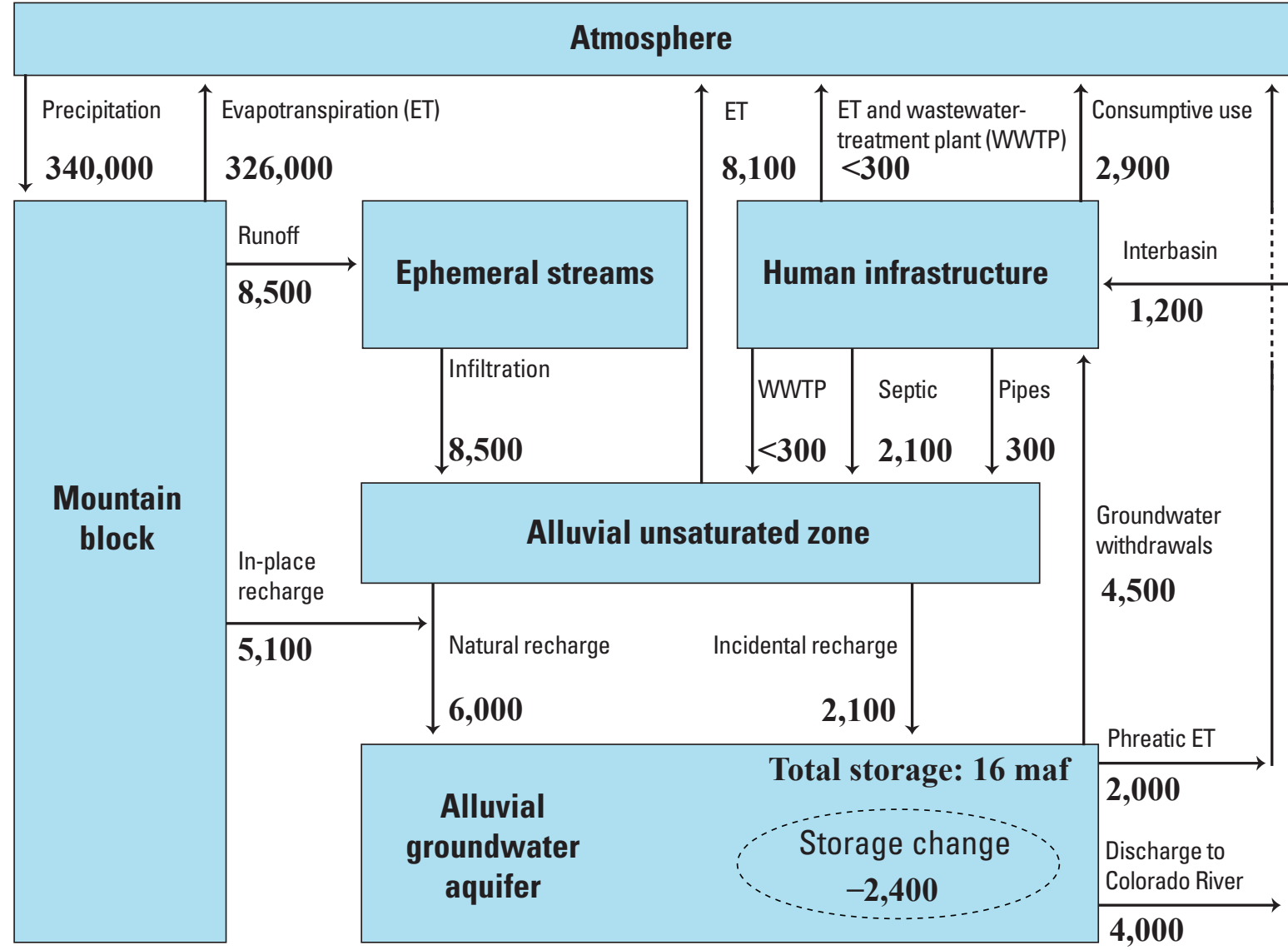

Figure 11. Water budget for Sacramento Valley showing recent (2007-08) human-driven effects and long-term (1940-2008) natural effects, Mohave County, Arizona. All units are acre-feet per year, unless otherwise indicated; maf, millions of acre-feet. 
Table 3. Groundwater-budget values for Sacramento Valley, Mohave County, Arizona. Includes values from previous studies for comparison.

[acre-ft/yr, acre-feet per year; maf, millions of acre-feet; $\leq$, less than or equal to; WWTP, wastewater-treatment plant; CWS, community water supplier; SSD, self-supplied domestic; ET, evapotranspiration]

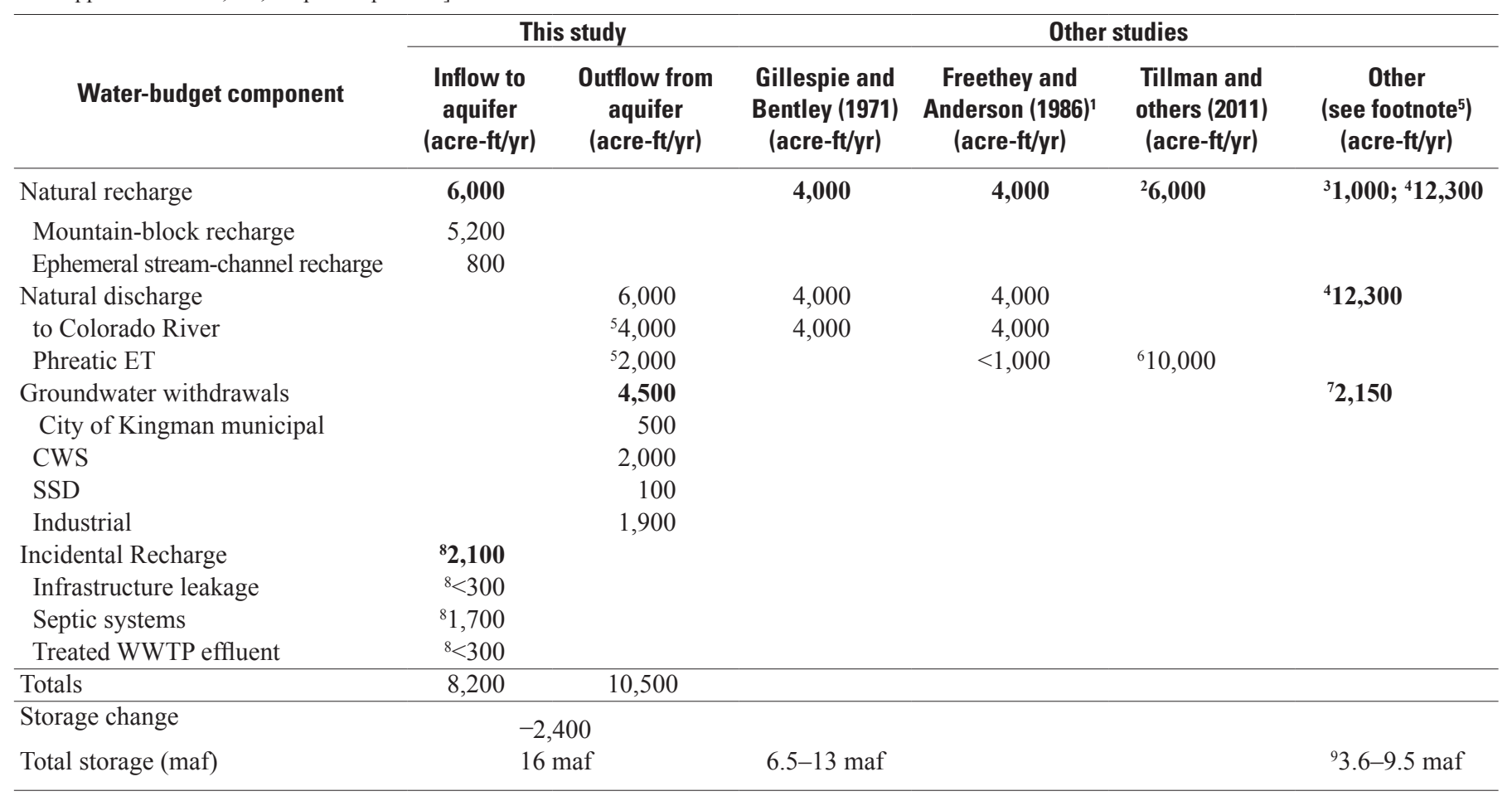

${ }^{1}$ Predevelopment. Values obtained from unpublished tabular data. Plates in report show only qualitative ranges of values.

${ }^{2}$ Based on re-running Freethey and Anderson (1986) models with revised precipitation data.

${ }^{3}$ Rascona (1991).

${ }^{4}$ Metzger and Loeltz (1973).

${ }^{5}$ Partitioning between Colorado River and phreatic ET uncertain because of a lack of data.

${ }^{6}$ Only 2,000 acre-ft/yr of this value occurs in zones with known woody and herbaceous plants.

${ }^{7}$ Tadayon (2005), value as of year 2000.

${ }^{8}$ Includes the effects of 1,200 acre-ft/yr of water transferred from Hualapai Valley for City of Kingman.

${ }^{9}$ Conway and Ivanich (2007).

3,800 and 7,000 acre-ft/yr of phreatic ET occurring within and along ephemeral stream channels in the valley; however, field verification of vegetation in these channels found no evidence of phreatophytes except possibly mesquite, which also can survive in nonphreatic conditions. Depths-to-water in wells near these stream channels range from 62 to more than $800 \mathrm{ft}$ (Anning and others, 2007). Because of the apparent "greenness" of these stream channels, the regional regression model used by Tillman and others appears to overestimate phreatic ET in these stream channels.

Tillman and others (2011) also indicated that about 2,000 acre-ft/yr of phreatic ET occurs in a zone of known woody/ herbaceous plants at the downstream end of Sacramento Wash. This zone coincides with a 700-acre stand of saltcedar (fig. 12) within Havasu NWR (see fig. 1). Saltcedar is an invasive plant that can obtain water from the groundwater system (Di Tomaso, 1998). Dividing Tillman's estimated 2,000 acre-ft/yr by 700 acres produces $3.1 \mathrm{ft} / \mathrm{yr}$ of water use, which is within a published range (2.5-4 ft/yr) for saltcedar-dominated riparian vegetation areas (Dahm and others, 2002).
Groundwater hydrology within Havasu NWR is complicated by diversions and dams associated with Topock Marsh (Guay and others, 2006; Guay, 2001). Groundwater used by saltcedar could be obtained from the Sacramento Valley alluvial aquifer, groundwater recharge from the Colorado River, or both. Additional data, particularly groundwater levels within and around Havasu NWR, would help to better understand the hydrology of this area. For the purposes of this water budget — and with the understanding that this value is uncertain - 2,000 acre- $\mathrm{ft} / \mathrm{yr}$ is estimated to return to the atmosphere from the Sacramento Valley alluvial aquifer through phreatic ET.

\section{Groundwater Withdrawals}

Groundwater withdrawals from the Sacramento Valley alluvial aquifer (2007-08) were about 4,500 acre-ft/yr, and an additional 1,200 acre-ft/yr was transferred into the valley from Hualapai Valley by the City of Kingman. About 
two-thirds of these withdrawals were used for municipal and domestic purposes; the remaining was used for industrial processes, primarily thermoelectric power generation. The City of Kingman required about 1,700 acre- $\mathrm{ft} / \mathrm{yr}$ of water to meet customer demand - $500 \mathrm{acre-ft/yr}$ by withdrawal from Sacramento Valley and 1,200 acre-ft/yr by a transfer from Hualapai Valley. CWSs withdrew about 2,000 acre-ft/yr, serving about 55 percent of the Sacramento Valley population. About 4 percent of the population ( 800 people) is estimated to be SSD, withdrawing less than 300 acre-ft/yr.

\section{Incidental Recharge}

About 2,100 acre-ft/yr of water (2007-08) recharged the Sacramento Valley alluvial aquifer as a result of human infrastructure and water use. Less than $300 \mathrm{acre}-\mathrm{ft} / \mathrm{yr}$ of this recharge was from leaks in water-supply lines, about 1,700 acre-ft/yr from septic-system drain fields, and less than 300 acre-ft/yr from treated effluent discharging from the City of Kingman WWTP in Sacramento Valley.

The WWTP in Sacramento Valley treated about 400 acre-ft/yr of effluent, but 1,100 acre-ft/yr of effluent was estimated to be produced by City of Kingman residents. As in Hualapai Valley, this discrepancy was explained by 60 percent of City of Kingman residents receiving municipal water but discharging effluent to septic systems instead of the WWTP. Three additional WWTPs in Sacramento Valley (Arizona Department of Water Resources, 2009b, p. 43) likely treated less than a combined $100 \mathrm{acre}-\mathrm{ft} / \mathrm{yr}$ of effluent, an amount considered to be negligible.

Almost two-thirds of water withdrawn from the Sacramento Valley alluvial aquifer (2007-08) was used consumptively, which is a larger proportion than is used by the other valleys in the study area. The reason for this was that there was a much larger amount of industrial water use in Sacramento Valley. Thermoelectric-power generation was one of the dominant industrial processes, and consumptive use occurs through two general pathways (World Nuclear Association, 2010). First, about 1 acre-ft of water evaporates from cooling towers for every 500 megawatt-hours of electricity produced. Second, blowdown water is discharged to offset the salinity buildup caused by cooling-tower evaporation; blowdown water enters lined evaporation ponds and returns to the atmosphere through evaporation.

\section{Groundwater Storage}

Groundwater storage was estimated to be decreasing at about 2,400 acre-ft/yr in the Sacramento Valley alluvial aquifer during 2007-08. While 4,500 acre-ft/yr was being withdrawn by pumping, about 2,100 acre-ft/yr was returning as incidental recharge. This suggests that about half of all withdrawn water returned as incidental recharge. However, about 30 percent of this incidental recharge was associated with an interbasin transfer from Hualapai Valley; excluding interbasin transfers, the ratio of incidental recharge to withdrawals is about 34 percent. Total groundwater storage to a depth of $1,300 \mathrm{ft}$ bls is estimated to be 16 maf, reflecting 2006 water-level conditions (M. Truini, U.S. Geological Survey, written commun., 2011).

\section{Discussion}

\section{Comparison with Other Studies}

Water budgets in this report generally contained higher natural recharge and discharge values than previously published values. In light of the varied approaches taken and the inherent uncertainty, estimated values in this report still are considered to be comparable to those of most previous reports. A summary of values from tables 1,2, and 3 is given here.

Freethey and Anderson's (1986) values for natural recharge and discharge are 33-50 percent less than those of this report. Their method for recharge-estimation used a linear equation relating precipitation above $8 \mathrm{in} / \mathrm{yr}$ to recharge across all alluvial basins of Arizona. Precipitation values used in the Freethey and Anderson (1986) recharge equation were estimated by using generalized, hand-contoured maps.

Natural-recharge values from Tillman and others (2011), estimated using the BCM, agree closely with values from this report. Tillman and others also re-applied the model of Freethey and Anderson (1986) using PRISM estimates of precipitation instead of hand-contoured precipitation maps; the resulting recharge estimates are higher than values reported by Freethey and Anderson (1986) and are similar to the values of this report. As discussed elsewhere, estimates of phreatic ET by Tillman and others (2011) generally are considered to be

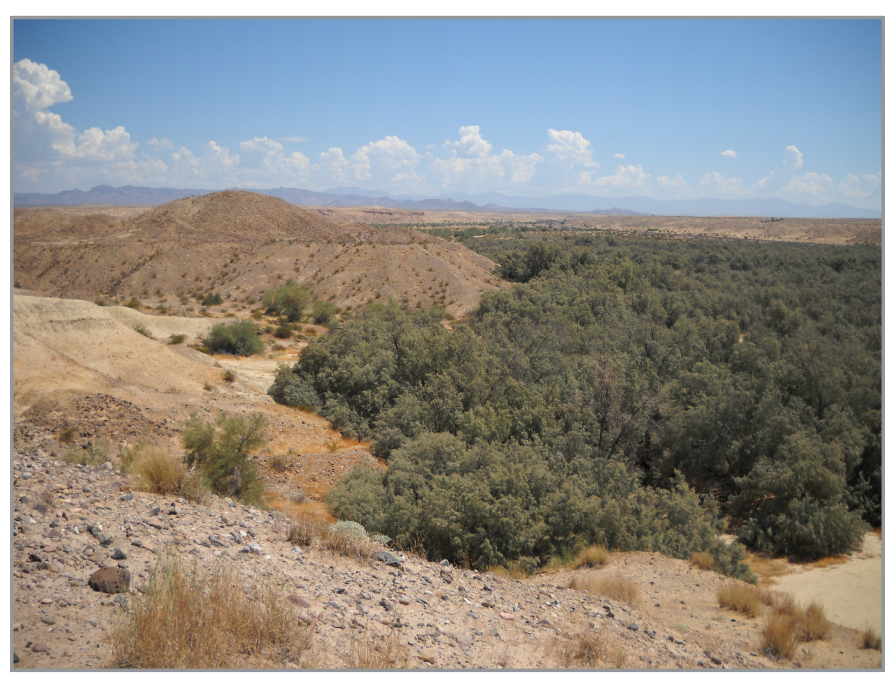

Figure 12. Stand of riparian vegetation dominated by saltcedar, looking upstream in Sacramento Wash, Havasu National Wildlife Refuge, Mohave County, Arizona. 
high for the study area in light of the additional spatial analyses and field verification described in this report.

Gillespie and Bentley's (1971) estimates of natural discharge from Hualapai and Sacramento Valleys are 24 and 33 percent less, respectively, than those of this report. Another difference between Gillespie and Bentley's report and this one was underflow between Hualapai Valley and Truxton Canyon. They estimated 1,000 acre-ft/yr of underflow exiting Hualapai Valley in the 1970s, whereas this report estimates 300 acre-ft/ yr of underflow entering Hualapai Valley in 2007-08. This discrepancy is discussed in the "Natural Recharge" subsection of the "Hualapai Valley Water Budget" section.

Two studies of Sacramento Valley reported values that disagree with those of this report. Rascona (1991) estimated natural groundwater discharge at 1,000 acre-ft/yr, four to six times less than other published values. However, Rascona subtracted groundwater withdrawals from natural discharge, an approach not taken in this report because groundwater withdrawals were assumed to have not yet depleted natural discharge or streamflow. Metzger and Loeltz (1973) estimated natural recharge and discharge each at 12,300 acre-ft/yr by applying an empirical relation between precipitation and recharge developed for central Nevada (Eakin and others, 1951, p. 79-81). This value is more than twice as large as any other published recharge or discharge value for Sacramento Valley.

\section{Effects of Groundwater Withdrawals}

From 1940 through 2008, total groundwater withdrawals are about 3,400 acre-ft for Detrital Valley, 270,000 acre-ft for Hualapai Valley, and 170,000 acre-ft for Sacramento Valley (fig. 13; appendix 1). These values are general estimates, as they do not include estimates of unreported withdrawals prior to 2007 and are based on historical data that contain uncertainty. These total withdrawals are low compared to those of other Arizona groundwater basins (for example, 134,000 acre-ft/yr is withdrawn from the Willcox Basin; Tadayon, 2005), but they are significant for the study area given the low natural-recharge rates.

Any amount of groundwater withdrawn by pumping is accounted for by some combination of decrease in groundwater storage, reduction in natural discharge, and(or) increase in natural recharge (Theis, 1940; Leake and others, 2008). Determining the distribution among these three effects typically is difficult without a groundwater-flow model. However, because of the locations of withdrawals to date in the study area and the large storage volumes of the alluvial aquifers, a reasonable assumption could be that all, or nearly all water withdrawn to date has been accounted for by storage depletion. The main supporting evidence for this assumption is that water-level declines, as of 2006, have not yet reached downgradient discharge areas (Anning and others, 2007). Mountain-front recharge in the study area is unlikely to be affected by withdrawals, because water tables are disconnected from mountain-front stream channels, and their lowering would not be able to induce additional recharge (Anderson, 1995).
Leake and others (2008) estimated that, after 100 years of continuous groundwater withdrawals near Dolan Springs in Detrital Valley, between 1 and 50 percent of withdrawn water would be accounted for by a reduction in natural discharge to and(or) increase in recharge from Lake Mead. This estimate is based on a simplified groundwater-flow model with a range of transmissivity values. Ultimately, there are only two possible long-term outcomes: (1) longterm groundwater withdrawals eventually (perhaps after centuries) obtain 100 percent of their water from reduction in discharge and(or) depletion of streamflow with no additional long-term storage depletion (Leake and others, 2008), or (2) long-term groundwater withdrawals are greater than all discharge or capturable streamflow, and the aquifer becomes depleted of all recoverable water. Estimating the time required for either of these ultimate outcomes to occur is beyond the scope of this report.

Continued withdrawals from the Kingman subbasin of Hualapai Valley will continue to lower water levels and steepen gradients, but such changes may be more pronounced because of the geometry of this subbasin. The Kingman subbasin is connected hydrologically to the adjacent Hualapai subbasin by alluvial fill that is only 300-600 ft deep (fig. 3), suggesting limited connectivity between the Kingman subbasin and other areas of Hualapai Valley. As water is withdrawn from the Kingman subbasin, water from other Hualapai Valley subbasins would flow preferentially toward the Kingman subbasin, but would be limited by the low transmissivity along its northern boundary.

\section{Incidental Recharge and Water Quality}

Across the study area, incidental recharge accounted for about 35 percent of total recharge, which could raise water-quality concerns (Asano and Cotruvo, 2004). Although incidental-recharge rates are small relative to total aquifer storage, localized water-quality issues might arise if wells are near areas of incidental recharge. Arizona regulatory agencies already have expressed concern about high groundwater nitrate concentrations in the Kingman subbasin of Hualapai Valley. Natural nitrate accumulations in the unsaturated zone can be mobilized by incidental recharge and result in high groundwater nitrate concentrations (Walvoord and others, 2003), however, no studies have been done to investigate this issue in the study area (J. Corwin, City of Kingman, oral commun., 2010). Incidental recharge from leaking water-supply pipes also can cause water-quality concerns. Disinfection by-products, such as trichloromethane, can be produced as drinking-water disinfectants interact with natural organic matter in the aquifer (Izbicki and others, 2010; Mahler and others, 2006). No studies of this process have been undertaken in the study area. 


\section{Limitations and Uncertainty in Water Budgets}

Water budgets are "lumped-parameter models," in that their values present average conditions both in space and over time. The reality is far more complex-groundwater systems have "complex, time-varying, three-dimensional flow systems" (Upper San Pedro Partnership, 2007, p. 41). This can limit the applicability of water budgets for answering detailed questions about groundwater systems, and groundwater-flow models could be required in those cases.

Uncertainty and sources of error often are not discussed at great length in water budgets, leading to a false sense of confidence in their values (Winter, 1981). Although a rigorous, quantitative estimate of uncertainty is beyond the scope of this report, qualitative discussions of limitations and major sources of uncertainty for natural recharge, natural discharge, incidental recharge, and storage are provided in this section.

\section{Natural Recharge}

Natural recharge values in this report are subject to uncertainty inherent in the BCM. Precipitation data used by the BCM (PRISM) can have absolute errors of more than 20 percent on an annual basis, particularly in mountainous areas of

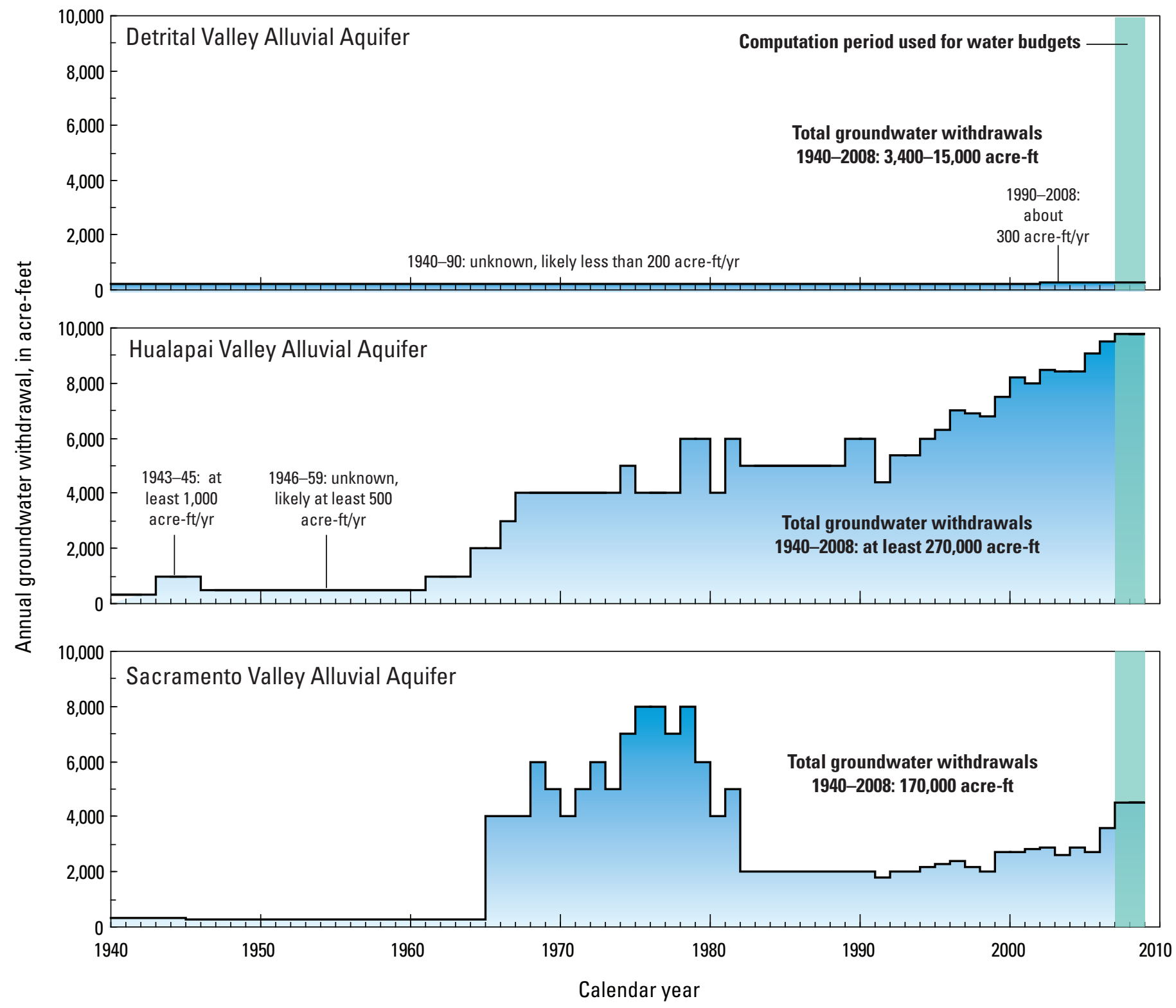

Figure 13. Groundwater withdrawals from Detrital, Hualapai, and Sacramento Valley alluvial aquifers, 1940-2008, Mohave County, Arizona. 
the western United States (Daly and others, 2008). BCM data for hydraulic properties of bedrock and soil are extrapolated to large regional areas on the basis of generalized geologic maps and have not been field-verified within this study area. Potential ET is estimated only as a single set of 12 monthly values in the $\mathrm{BCM}$, instead of as a time-series dataset, as for precipitation.

Another consideration is that the $\mathrm{BCM}$ runs at a monthly time-step and, consequently, cannot model intense, short-duration thunderstorms. Such thunderstorms can produce localized precipitation that, on the scale of hours, exceeds potential ET and becomes recharge. On a monthly time-scale, however, cumulative precipitation from small thunderstorms is much less than total potential ET. The amount of recharge occurring in this manner and not accurately modeled by the BCM is not known for the study area.

For this report, 10 percent of BCM runoff eventually was assumed to become recharge. This single value encapsulates a number of processes and variability, including location, lithology, antecedent conditions, precipitation intensity, and season. Vegetation also affects this value, as can upward movement of unsaturated-zone water caused by thermal gradients (de Vries and Simmers, 2002). Additional field studies - or possibly a calibrated groundwater-flow model — would be needed to better constrain this value.

The period 1940-2008 was used to estimate natural recharge, but it might not fully capture true average conditions. A 1904 winter flood in Truxton Canyon had a peak discharge of 49,000 ft³/s (Murphy, 1905). A September 1939 storm produced a peak discharge of $15,000 \mathrm{ft}^{3} / \mathrm{s}$ in Sacramento Wash near the Colorado River (Metzger and Loeltz, 1973, p. 18). These and other rare flood events indicate that a longer period of record might produce different recharge estimates.

Although water budgets in this report present natural recharge as a single estimate of long-term, mean-annual recharge, natural variability of recharge is important to remember (de Vries and Simmers, 2002). Natural recharge's interannual variability spans more than four orders of magnitude within the study area (fig. 14), a characteristic common to the arid southwest. For about 30 percent of the years 1940-2008, annual recharge to Hualapai and Sacramento Valleys was less than 300 acre-ft; for Detrital Valley, 60 percent of years 1940-2008 had annual recharge of less than 300 acre-ft. At the other extreme, the three years that produced the greatest amount of natural recharge $(1993,2005$, and 1978) were 5-8 times greater than the mean-annual recharge values shown in this report.

\section{Natural Discharge}

As stated throughout this report, natural discharge is assumed to be equal to natural recharge even though groundwater withdrawals have occurred since about 1940 . This assumption is considered reasonable for 2007-08 conditions, but at some point after 2008 it will no longer be valid.

Direct measurements of natural discharge would be ideal, but are not practical for several reasons. Lake Mead has inundated most historical springs (Longwell, 1936) that presumably discharged groundwater from the alluvial aquifers of Detrital and Hualapai Valleys. Impoundments of and diversions from the Colorado River near Havasu NWR have changed the groundwater-discharge regime of the Sacramento Valley alluvial aquifer. Finally, groundwater discharge to the Colorado River in the study area is more than four orders of magnitude less than average Colorado River discharge. A method capable of detecting less than a 1 part in 1,000 change in streamflow presently is not practical.

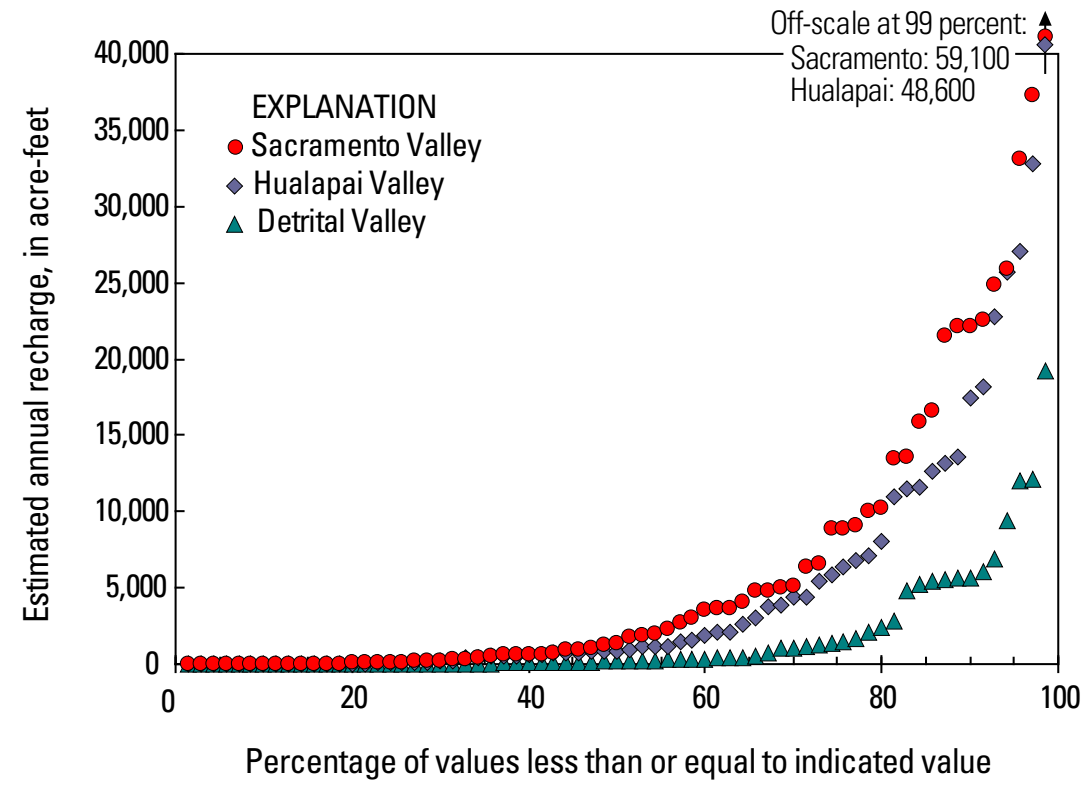




\section{Groundwater Withdrawals}

Groundwater withdrawals by municipal, industrial, and CWSs estimated in this report are subject to uncertainties inherent in these data, including inaccurate flowmeters and incomplete or erroneous reporting of withdrawals. Withdrawals by the SSD population were estimated by using census data; part-year, winter-only residents cause additional uncertainty because they might or might not be counted in the census.

\section{Incidental Recharge}

Incidental-recharge values in this report relied on generalized percentages from studies in similar areas. Many additional processes, including lawn over watering, impervious-cover changes, stream-channel lining, and soil disturbance can affect incidental recharge rates (Scanlon and others, 2006; Shuster and others, 2005) but were not considered. Another factor to consider is the accuracy of groundwater-withdrawal data reported to State agencies because incidental recharge rates are directly proportional to groundwater withdrawal rates. Finally, part-year, winter-only residents likely cause additional uncertainty because they would use more water in the winter than summer and, therefore, could cause consumptive use to be underestimated.

\section{Total Groundwater Storage}

Total groundwater-storage values can be misleading from a resource-management perspective, because they likely do not reflect the actual amount of practically recoverable water (Alley, 2007). In a scenario where groundwater storage is being continually depleted, removal of all groundwater from storage by pumping is impossible from a practical standpoint. Land subsidence, changes in water quality, and increased pumping costs likely would be encountered long before the full reservoir of groundwater storage was depleted.

\section{Summary}

The USGS, in cooperation with ADWR, initiated a study of the hydrogeology and water resources of Detrital, Hualapai, and Sacramento Valleys in 2005. These valleys primarily have a rural but growing population, and the people and industries in them rely almost entirely on groundwater. Effects of human groundwater use are evident, as indicated by water-level declines of more than $130 \mathrm{ft}$ in some areas. The purpose of this report is to present water budgets for each of the valleys, in order to address fundamental hydrologic questions about water input, output, and storage.

The study area is within the Basin and Range physiographic province. Here, alluvial basins are bounded and underlain by low-permeability igneous and metamorphic rocks (bedrock) and filled with thousands of feet of alluvial fill eroded from surrounding mountain blocks beginning 13-16 million years ago. The climate is arid to semiarid, having average annual precipitation of about 9.2 inches, and no major perennial-stream reaches. Detrital Valley has an area of 900 $\mathrm{mi}^{2}$, has groundwater flow from south to north toward Lake Mead, and is sparsely populated. Hualapai Valley has an area of 1,200 $\mathrm{mi}^{2}$, has a closed-basin surface-water system draining to Red Lake Playa, but has groundwater flow from south to north toward Lake Mead. Sacramento Valley has an area of 1,600 $\mathrm{mi}^{2}$, and groundwater flows generally north to south then west toward the Colorado River.

Water budgets were presented by using a reservoir-andconveyance approach, wherein water moves between reservoirs (such as the unsaturated zone and the alluvial aquifer) by way of conveyances as a result of natural and human processes (such as infiltration, groundwater withdrawals, and groundwater discharge). Average values for natural processes were estimated using the period from 1940 to 2008, and average values for human processes were estimated from 2007-08 data.

Natural recharge from precipitation was calculated by using a physically based distributed model (the BCM) that calculated recharge and runoff at monthly intervals on the basis of precipitation, climate, soil, and geology hydraulic-property data. Estimated discharge from upland springs was subtracted from recharge and added to runoff, and 10 percent of runoff was assumed to become recharge. Water also entered Hualapai Valley from an adjacent upgradient valley.

Natural discharge is assumed to be equal to natural recharge, reflecting a key assumption that groundwater withdrawals to date have not yet reduced discharge or depleted streamflow. Discharge occurs primarily as groundwater discharge to Lake Mead or the Colorado River. Some discharge also can occur when groundwater is used by vegetation, particularly in Sacramento Valley near Havasu NWR.

Groundwater withdrawals were calculated by compiling data from the City of Kingman, CWSs, industrial facilities, and by estimating withdrawals of the SSD population. Withdrawals by the SSD population were estimated by using census data, because these withdrawals are neither monitored nor reported to State agencies.

Incidental recharge-recharge that occurs as result of human infrastructure and water use - was estimated for leaking water-supply pipes, septic systems, and WWTPs. Twenty-eight percent of groundwater withdrawn for domestic use is estimated not to become recharge because of consumptive use. One-hundred percent of groundwater used for industrial processes is assumed to be consumptively used. Fifty-two percent of water treated at WWTPs is estimated to return to the atmosphere through ET. Of the remaining water, 80 percent is assumed to become recharge.

Annual changes in groundwater storage were calculated as the residuals of inputs subtracted from outputs. Because of assumptions, storage change ultimately reflected only the imbalance between groundwater withdrawals and incidental recharge.

Natural recharge and discharge for the Detrital Valley alluvial aquifer both are about 1,400 acre-ft/yr each. Natural 
discharge occurs as groundwater discharge to Lake Mead. Springs below the maximum lake level of Lake Mead might or might not represent discharge from the alluvial aquifer; bank storage from Lake Mead could be the source of some or all of their discharge. Groundwater withdrawals and incidental recharge each were less than 300 acre-ft/yr in 2007-08. Groundwater storage is decreasing at rates less than $300 \mathrm{acre}-\mathrm{ft} / \mathrm{yr}$. Total groundwater storage is estimated to be 4.5 maf.

Natural recharge and discharge for the Hualapai Valley alluvial aquifer each are about 5,700 acre-ft/yr. Natural discharge occurs as groundwater discharge to Lake Mead. Of this total recharge, $900 \mathrm{acre}-\mathrm{ft} / \mathrm{yr}$ is estimated to be from water entering the valley in or beneath Truxton Wash from an upgradient valley; this value is uncertain because of alteration to the natural system in that valley by pumping. Groundwater withdrawals are about 9,800 acre-ft/yr, with $1,200 \mathrm{acre}-\mathrm{ft} / \mathrm{yr}$ of this being transferred to Sacramento Valley for use in that valley. Most of the remaining 8,600 acre- $\mathrm{ft} / \mathrm{yr}$ is for domestic and municipal use in the City of Kingman. Incidental recharge was about 4,200 acre-ft/yr in 2007-08. Groundwater storage was decreasing by about $5,600 \mathrm{acre}-\mathrm{ft} / \mathrm{yr}$ as of $2007-08$. Total groundwater storage is estimated to be 15 maf.

Natural recharge and discharge for the Sacramento Valley alluvial aquifer each are about 6,000 acre-ft/yr. Natural discharge mostly occurs as groundwater discharge to the Colorado River, although up to 2,000 acre-ft/yr could occur as phreatic ET near Havasu NWR. Groundwater withdrawals are about 4,500 acre-ft/yr, with an additional $1,200 \mathrm{acre}-\mathrm{ft} / \mathrm{yr}$ transferred into the valley from Hualapai Valley. Incidental recharge is about 2,100 acre-ft/yr. Consumptive use is higher in Sacramento Valley than in the other valleys in the study area because of a higher amount of industrial water use. Groundwater storage was decreasing at about 2,400 acre-ft/yr as of 2007-08. Total groundwater storage is estimated to be 16 maf.

Water budgets in this report had natural recharge and discharge values that are 24-50 percent greater than most previously published values; this difference is not considered unreasonable given the varied approaches and uncertainty inherent in these calculations. Two previous studies of Sacramento Valley disagreed with values in this report, but the methods used in those reports were based on markedly different assumptions.

From 1940 through 2008, about 3,400 acre-ft, 270,000 acre-ft, and 170,000 acre-ft of water were withdrawn from Detrital, Hualapai, and Sacramento Valley alluvial aquifers, respectively. Through 2008 these withdrawals likely have been derived almost entirely from storage depletion, but at some point after 2008, this will no longer be the case. Withdrawals in the Kingman subbasin of Hualapai Valley could produce more pronounced water-level declines than withdrawals in other areas because of limited transmissivity between this subbasin and adjacent ones.
Incidental recharge is an important recharge component, accounting for about 35 percent of total recharge in the study area as of 2007-08; however, there could be water-quality concerns, such as increased concentrations of nitrate and disinfection by-products as a result of this recharge.

There are many sources of uncertainty for water budgets in this report that should be kept in mind. Natural recharge estimates incorporate uncertainty that is inherent in the BCM, as well as additional uncertainty caused by the BCM monthly time-step and the assumption that 10 percent of runoff becomes recharge. Although natural recharge is presented as a single mean-annual number in this report, it varies considerably from year to year. Incidental recharge estimates relied on generalized percentages from other studies and ignored some possible effects. Total groundwater-storage values in this report should be interpreted carefully because it is unlikely that it is practical to recover all of this groundwater in storage.

\section{References Cited}

Alley, W.M., 2007, Another water budget myth-The significance of recoverable ground water in storage: Ground Water, v. 45, no. 3, p. 251.

Anderson, T.W., 1995, Summary of the Southwest Alluvial Basins, Regional Aquifer-System Analysis, south-central Arizona and parts of adjacent states: U.S. Geological Survey Professional Paper 1406-A, 33 p.

Anning, D.W., and Duet, N.R., 1994, Summary of groundwater conditions in Arizona, 1987-90: U.S. Geological Survey Open-File Report 94-476, 2 p.

Anning, D.W., Flynn, M.E., and Truini, Margot, 2006, Hydrogeologic investigation of the Detrital, Hualapai, and Sacramento Valleys of northwestern Arizona-A project of the Rural Watershed Initiative: U.S. Geological Survey Fact Sheet 2006-3008, 4 p.

Anning, D.W., and Konieczki, A.D., 2005, Classification of hydrogeologic areas and hydrogeologic flow systems in the basin and range physiographic province, southwestern United States: U.S. Geological Survey Professional Paper 1702, 37 p.

Anning, D.W., Truini, Margot, Flynn, M.E., and Remick, W.H., 2007, Ground-water occurrence and movement, 2006, and water-level changes in the Detrital, Hualapai, and Sacramento valley basins, Mohave County, Arizona: U.S. Geological Survey Scientific Investigations Report 2007-5182, 24 p.

Arizona Corporation Commission, 2010, Water company annual reports, accessed May 18, 2010, at http://www.azcc. gov/divisions/utilities/Annual\%20Reports/water.asp. 
Arizona Department of Water Resources, 2009a, ADWR GIS, water resource data, accessed June 1, 2009, at http://gisweb. azwater.gov/waterresourcedata/ .

Arizona Department of Water Resources, 2009b, Arizona water atlas, accessed June 23, 2010, at http:/www.azwater.gov/ azdwr/StatewidePlanning/WaterAtlas/UpperColoradoRiver/.

Arizona Department of Water Resources, 2005, Upper San Pedro Basin active management area review report, 219 p.

Asano, Takashi, and Cotruvo, J.A., 2004, Groundwater recharge with reclaimed municipal wastewater - health and regulatory considerations: Water Research, v. 38, p. 1941-1951.

Babcock, H.M., and others, 1969, Annual report on ground water in Arizona, spring 1968 to spring 1969: Arizona State Land Department Water-Resources Report 42, 46 p.

Babcock, H.M., and others, 1970, Annual report on ground water in Arizona, spring 1969 to spring 1970: Arizona State Land Department Water-Resources Report 43, 44 p.

Babcock, H.M., and others, 1972, Annual report on ground water in Arizona, spring 1970 to spring 1971: Arizona State Land Department Water-Resources Report.

Bales, J.T., and Laney, R.L., 1992, Geohydrologic reconnaissance of Lake Mead National Recreation Area; Virgin River, Nevada, to Grand Wash Cliffs, Arizona: U.S. Geological Survey Water-Resources Investigations Report 91-4185, 29 p.

Beard, L.S., Kennedy, J.T., Truini, Margot, and Felger, T.J., (in press), Geologic map of Detrital, Hualapai, and Sacramento Valley Basins, northwest Arizona: U.S. Geological Survey Open-File Report, 1 sheet, scale $1: 250,000$

Berger, D.L., 2000, Water budget estimates for the 14 hydrographic areas in the middle Humboldt River Basin, north-central Nevada: U.S. Geological Survey WaterResources Investigations Report 00-4168, 55 p.

Conway, B.D., and Ivanich, P.A., 2007, Preliminary estimate of water in storage for the Sacramento Valley ground-water basin, Mohave County, Arizona: Arizona Department of Water Resources Open-File Report 10, 48 p.

Cox, C.J., and others, 1968, Annual report on ground water in Arizona, spring 1966 to spring 1967: Arizona State Land Department Water-Resources Report 36, 43 p.

Dahm, C.N., Cleverly, J.R., Coonrod, J.E.A., Thibault, J.R., McDonnell, D.E., and Gilroy, D.J., 2002, Evapotranspiration at the land/water interface in a semi-arid drainage basin: Freshwater Biology, v. 47, p. 831-843.
Daly, Christopher, Gibson, W.P., Taylor, G.H., Johnson, G.L., and Pasteris, P.P., 2002, A knowledge-based approach to the statistical mapping of climate: Climate Research, v. 22, p. 99-113.

Daly, Christopher, Halbleib, Michael, Smith, J.I., Gibson, W.P., Doggett, M.K., Taylor, G.H., Curtis, Jan, and Pasteris, P.P., 2008, Physiographically sensitive mapping of climatological temperature and precipitation across the conterminous United States: International Journal of Climatology, v. 28, no. 15, p. 2031-2064.

de Vries, J.J., and Simmers, Ian, 2002, Groundwater recharge - an overview of processes and challenges: Hydrogeology Journal, v. 10, no. 1, p. 5-17.

Di Tomaso, J.M., 1998, Impact, biology, and ecology of Saltcedar (Tamarix spp.) in the southwestern United States: Weed Technology, v. 12, p. 326-336.

Eakin, T.E., Maxey, G.B., Robinson, T.W., Fredericks, J.C., and Loeltz, O.J., 1951, Contributions to the hydrology of eastern Nevada: Nevada Water Resources Bulletin 12, 171 p.

Fenneman, N.M., 1931, Physiography of the western United States: New York, McGraw-Hill, 534 p.

Flint, A.L., and Ellett, K.M., 2004, The role of the unsaturated zone in artificial recharge at San Gorgonio Pass, California: Vadose Zone Journal, v. 3, no. 3, p. 763-774.

Flint, A.L., and Flint, L.E., 2007a, Application of the Basin Characterization Model to estimate in-place recharge and runoff potential in the Basin and Range carbonaterock aquifer system, White Pine County, Nevada, and adjacent areas in Nevada and Utah: U.S. Geological Survey Scientific Investigations Report 2007-5099, 21 p.

Flint, L.E., and Flint, A.L., 2007b, Regional analysis of ground-water recharge, in Ground-water recharge in the arid and semiarid southwestern United States: U.S. Geological Survey Professional Paper 1703, p. 29-60.

Freethey, G.W., and Anderson, T.W., 1986, Predevelopment hydrologic conditions in the alluvial basins of Arizona and adjacent parts of California and New Mexico: U.S. Geological Survey Hydrologic Atlas 664, 3 p.

Gillespie, J.B., and Bentley, C.B., 1971, Geohydrology of Hualapai and Sacramento Valleys, Mohave County, Arizona: U.S. Geological Survey Water Supply Paper 1899-H, 37 p.

Guay, B.E., 2001, Preliminary hydrologic investigation of Topock Marsh, Arizona 1995-98: University of Arizona, PhD dissertation, $334 \mathrm{p}$. 
Guay, B.E., Eastoe, C.J., Bassett, Randall, and Long, Austin, 2006, Identifying sources of groundwater in the lower Colorado River Valley, USA, with $\delta^{18} \mathrm{O}, \delta \mathrm{D}$, and ${ }^{3} \mathrm{H}$; implications for river water accounting: Hydrogeology Journal, v. 14, no. 1-2, p. 146-158.

Hawkins, Dave, 2009, World's largest solar-thermal plant planned for Arizona land sold by Rhodes: Las Vegas Review-Journal, accessed June 23, 2010, at http://www.lvrj. com/business/44775192.html .

Healy, R.W., Winter, T.C., LaBaugh, J.W., and Franke, O.L., 2007, Water budgets-Foundations for effective waterresources and environmental management: U.S. Geological Survey Circular 1308, 90 p.

Heilweil, V.M., Solomon, D.K., and Gardner, P.M., 2007, Infiltration and recharge at Sand Hollow, an upland bedrock basin in southwestern Utah: U.S. Geological Survey Professional Paper 1703, p. 221-251.

Hodges, E.B., and others, 1967, Annual report on ground water in Arizona, spring 1965 to spring 1966: Arizona State Land Department Water-Resources Report 32, 61 p.

Ivanich, P.A., and Conway, B.D., 2007, Preliminary estimate of water in storage for the Hualapai Valley ground-water basin, Mohave County, Arizona: Arizona Department of Water Resources Open-File Report 9.

Izbicki, J.A., Petersen, C.E., Glotzback, K.J., Metzger, L.F., Christensen, A.H., Smith, G.A., O’Leary, D., Fram, M.S., Joseph, Trevor, and Shannon, Heather, 2010, Aquifer Storage Recovery (ASR) of chlorinated municipal drinking water in a confined aquifer: Applied Geochemistry, v. 24, no. 8, p. 1133-1152.

Jacobs, K.L., and Stitzer, L.S., 2007, Water supply and management in rural Arizona, in Arizona water policy: Management innovations in an urbanizing, arid region, Issues in water resource policy, Resources for the Future, Washington, D.C., p. 173-187.

Johnson, Greg, and Taylor, G.H., 2010, The NRCS PRISM climate mapping project: Corvallis, Oregon State University, Oregon Climate Service, accessed June 23, 2010, at http:// www.prismclimate.org/ .

Laney, R.L., 1979, Geohydrologic reconnaissance of Lake Mead National Recreation Area - Temple Bar to Grand Wash Cliffs, Arizona: U.S. Geological Survey Open-File Report 79-688, 72 p.

LaTour, J.K., 1991, Determination of water use in Rockford and Kankakee areas, Illinois: U.S. Geological Survey WaterResources Investigations Report 90-4166, 70 p.

Leake, S.A., Greer, William, Watt, Dennis, and Weghorst, Paul, 2008, Use of superposition models to simulate possible depletion of Colorado River water by groundwater withdrawal: U.S. Geological Survey Scientific Investigations Report 2008-5189, 25 p.
Longwell, C.R., 1936, Geology of the Boulder Reservoir floor, Arizona-Nevada: Geological Society of America Bulletin, v. 47, no. 9, p. 1393-1476.

Mahler, B.J., Garner, B.D., Musgrove, MaryLynn, Guilfoyle, A.L., and Rao, M.V., 2006, Recent (200305) water quality of Barton Springs, Austin, Texas, with emphasis on factors affecting variability: U.S. Geological Survey Scientific Investigations Report 2006-5299, 83 p.

Mason, D.A., Ivanich, P.A., Conway, B.D., Kurtz, J.A., and Winn, M.T., 2007, Preliminary estimate of water in storage for the Detrital Valley ground-water basin, Mohave County, Arizona: Arizona Department of Water Resources Open-File Report 9.

Mcbride, M.S., and Pfannkuch, H.O., 1975, The distribution of seepage within lake beds: Journal of Research of the U.S. Geological Survey, v. 3, no. 5, p. 505-512.

Metzger, D.G., and Loeltz, O.J., 1973, Geohydrology of the Needles area, Arizona, California, and Nevada: U.S. Geological Survey Professional Paper 486-J, 54 p.

Moore, S.J., 2007, Streamflow, infiltration, and recharge in Arroyo Hondo, New Mexico: U.S. Geological Survey Professional Paper, 1703, p. 137-155.

Murphy, E.C., 1905, Destructive floods in the United States in 1904: U.S. Geological Survey Water Supply Paper 147, 206 p.

Nishikawa, Tracy, Izbicki, J.A., Hevesi, J.A., Stamos, C.L., and Martin, Peter, 2004, Evaluation of geohydrologic framework, recharge estimates and ground-water flow of the Joshua Tree area, San Bernardino County, California: U.S. Geological Survey Scientific Investigations Report 2004-5267, 115 p.

Pfaff, C.L., and Clay, D.M., 1979, Map showing groundwater conditions in the Sacramento Valley area, Mohave County, Arizona: U.S. Geological Survey Open-File Report 81-418, 1 pl.

Phillips, F.M., 1994, Environmental tracers for water movement in desert soils of the American Southwest: Soil Science Society of America Journal, v. 58, no. 1, p. 15-24.

Pool, D.R., 2005, Variations in climate and ephemeral channel recharge in southeastern Arizona, United States: Water Resources Research, v. 41, p. W11403.

Pool, D.R., and Eychaner, J.H., 1995, Measurements of aquifer-storage change and specific yield using gravity surveys: Ground Water, v. 33, no. 3, p. 425-432. 
Rascona, S.J., 1991, Map showing groundwater conditions in the Sacramento Valley Basin, Mohave County, Arizona: State of Arizona Department of Water Resources, Hydrologic Map Series Report 21, 1 pl.

Scanlon, B.R., Keese, K.E., Flint, A.L., Flint, L.E., Gaye, C.B., Edmunds, W.M., and Simmers, Ian, 2006, Global synthesis of groundwater recharge in semiarid and arid regions: Hydrological Processes, v. 20, no. 15, p. $3335-$ 3370 .

Shaffer, K.H., 2009, Variations in withdrawal, return flow, and consumptive use of water in Ohio and Indiana, with selected data from Wisconsin, 1999-2004: U.S. Geological Survey Scientific Investigations Report 2009-5096, 93 p.

Sharp, J.M. Jr., and Garcia-Fresca, Beatriz, 2003, Effects of urbanization of groundwater resources, recharge rates, and flow patterns [abs.]: Geological Society of America Abstracts with Programs, v. 35, no. 6, p. 158, accessed Dec 2, 2008, at http:/gsa.confex.com/gsa/2003AM/ finalprogram/abstract_59125.htm .

Shuster, W.D., Bonta, J., Thurston, H., Warnemuende, E., and Smith, D.R., 2005, Impacts of impervious surface on watershed hydrology - A review: Urban Water Journal, v. 2, no. 4, p. 263.

Stewart-Deaker, A.E., Stonestrom, D.A., and Moore, S.J., 2007, Streamflow, infiltration, and ground-water recharge at Abo Arroyo, New Mexico: U.S. Geological Survey Professional Paper 1703, p. 83-105.

Stonestrom, D.A., Prudic, D.E., Walvoord, M.A., Abraham, J.D., Stewart-Deaker, A.E., Glancy, P.A., Constantz, J., Laczniak, R.J., and Andraski, B.J., 2007, Focused ground-water recharge in the Amargosa desert basin: U.S. Geological Survey Professional Paper 1703, p. 107-136.

Sweeting, M.M., 1973, Karst Landforms: New York, Columbia University Press, 362 p.

Tadayon, Saeid, 2005, Water withdrawals for irrigation, municipal, mining, thermoelectric-power, and drainage uses in Arizona outside of active management areas, 19912000: U.S. Geological Survey Scientific Investigations Report 2004-5293, 38 p.

Theis, C.V., 1940, The source of water derived from wells: Civil Engineering, v. 10, p. 277-280.

Tillman, F.D., Cordova, J.T., Leake, S.A., Thomas, B.E., Callegary, J.B., and Rautenkranz, D.S., 2011, Water availability and use pilot-Methods development for a regional assessment of groundwater availability, southwest alluvial basins, Arizona: U.S. Geological Survey Scientific Investigations Report 2011-5071, 118 p.
Treese, Samantha, Meixner, Thomas, and Hogan, J.F., 2009, Clogging of an effluent dominated semiarid river-A conceptual model of streamaquifer interactions: Journal of the American Water Resources Association, v. 45, no. 4, p. 1047-1062.

Upper San Pedro Partnership, 2007, Water management of the regional aquifer in the Sierra Vista subwatershed, Arizona-2007 report to Congress, $77 \mathrm{p}$.

U.S. Census Bureau, 2010a, American factfinder download center, accessed May 12, 2010, at http://factfinder.census.gov/servlet/ DownloadDatasetServlet .

U.S. Census Bureau, 2010b, Population estimates data sets, accessed May 25, 2010, at http://www. census.gov/popest/datasets.html .

Walvoord, M.A., Phillips, F.M., Stonestrom, D.A., Evans, R.D., Hartsough, P.C., Newman, B.D., and Striegl, R.G., 2003, A reservoir of nitrate beneath desert soils: Science, v. 302, no. 5647, p. 1021-1024.

Walvoord, M.A., Stonestrom, D.A., Andraski, B.J., and Striegl, R.G., 2004, Constraining the inferred paleohydrologic evolution of a deep unsaturated zone in the Amargosa Desert: Vadose Zone Journal, v. 3, no. 2, p. 502-512.

White, N., and others, 1965, Annual report on ground water in Arizona, spring 1964 to spring 1965: Arizona State Land Department WaterResources Report 24, 62 p.

White, N.D., Stulik, R.S., Morse, E.K., and others, 1963, Annual report on ground water in Arizona, spring 1962 to spring 1963: Arizona State Land Department Water-Resources Report 15, 136 p.

White, N.D., Stulik, R.S., Morse, E.K., and others, 1964, Annual report on ground water in Arizona, spring 1963 to spring 1964: Arizona State Land Department Water-Resources Report 19, 60 p.

Winter, T.C., 1981, Uncertainties in estimating the water balance of lakes: Journal of the American Water Resources Association, v. 17, no. 1, p. 82-115.

World Nuclear Association, 2010, Cooling power plants, accessed Jun 22, 2010, at http://www. world-nuclear.org/info/cooling_power_plants inf121.html. 
This page left intentionally blank. 


\section{Appendixes}




\section{Appendix 1. Historic Groundwater-Withdrawal Data}

A summary of available groundwater-withdrawal data for Detrital, Hualapai, and Sacramento Valleys is presented here (table 1.1). Data were compiled from sources that vary in accuracy and reporting limits.

Detrital Valley alluvial aquifer groundwater withdrawals appear to have been always less than 1,000 acre-ft/yr, in support mostly of rural and domestic water uses. Quantitative data are available beginning in 1991 (Tadayon, 2005), and from 1991 to 2008, withdrawals increased. Withdrawals before 1991 are assumed to be less than the value reported for 1991 . Total cumulative groundwater withdrawals from the Detrital Valley alluvial aquifer from 1940 to 2008 are at least 3,400 acre-ft and likely less than 15,000 acre-ft.

Hualapai Valley alluvial aquifer groundwater withdrawals probably first exceeded 1,000 acre-ft/yr from 1943 to 1945 when wells were operated to support an army gunnery school at the City of Kingman Airport (Gillespie and Bentley, 1971). Withdrawal amounts from 1946 to 1960 are unknown but likely are at least $500 \mathrm{acre}-\mathrm{ft} / \mathrm{yr}$ because one of these wells yielded more than $250 \mathrm{gal} / \mathrm{min}$. By 1961, groundwater withdrawals were consistently

Table 1.1. Annual groundwater withdrawals for Detrital, Hualapai, and Sacramento Valleys, 1940-2008, Mohave County, Arizona.

[acre-ft/yr, acre feet per year; <, less than indicated amount; >, greater than indicated amount; (parenthesized value) indicates alternate value obtained from unpublished USGS data]

\begin{tabular}{|c|c|c|c|}
\hline Year & $\begin{array}{l}\text { Detrital Valley } \\
\text { (acre-ft/yr) }\end{array}$ & $\begin{array}{c}\text { Hualapai Valley } \\
\text { (acre-ft/yr) }\end{array}$ & $\begin{array}{c}\text { Sacramento Valley } \\
\text { (acre-ft/yr) }\end{array}$ \\
\hline 1940 & ${ }^{1}<200$ & ${ }^{2}<300$ & ${ }^{2}<300$ \\
\hline 1941 & ${ }^{1}<200$ & ${ }^{2}<300$ & ${ }^{2}<300$ \\
\hline 1942 & ${ }^{1}<200$ & ${ }^{2}<300$ & ${ }^{2}<300$ \\
\hline 1943 & ${ }^{1}<200$ & ${ }^{3}>1,000$ & ${ }^{2}<300$ \\
\hline 1944 & ${ }^{1}<200$ & ${ }^{3}>1,000$ & ${ }^{2}<300$ \\
\hline 1945 & ${ }^{1}<200$ & ${ }^{3}>1,000$ & ${ }^{4} 250$ \\
\hline 1946 & ${ }^{1}<200$ & ${ }^{5} 500$ & ${ }^{4} 250$ \\
\hline 1947 & $1<200$ & 5500 & ${ }^{4} 250$ \\
\hline 1948 & ${ }^{1}<200$ & ${ }^{5} 500$ & ${ }^{4} 250$ \\
\hline 1949 & ${ }^{1}<200$ & ${ }^{5} 500$ & ${ }^{4} 250$ \\
\hline 1950 & ${ }^{1}<200$ & ${ }^{5} 500$ & ${ }^{4} 250$ \\
\hline 1951 & ${ }^{1}<200$ & ${ }^{5} 500$ & ${ }^{4} 250$ \\
\hline 1952 & ${ }^{1}<200$ & ${ }^{5} 500$ & ${ }^{4} 250$ \\
\hline 1953 & ${ }^{1}<200$ & ${ }^{5} 500$ & ${ }^{4} 250$ \\
\hline 1954 & ${ }^{1}<200$ & ${ }^{5} 500$ & ${ }^{4} 250$ \\
\hline 1955 & ${ }^{1}<200$ & 5500 & ${ }^{4} 250$ \\
\hline 1956 & ${ }^{1}<200$ & 5500 & ${ }^{4} 250$ \\
\hline 1957 & ${ }^{1<200}$ & 5500 & ${ }^{4} 250$ \\
\hline 1958 & ${ }^{1}<200$ & 5500 & ${ }^{4} 250$ \\
\hline 1959 & ${ }^{1}<200$ & ${ }^{5} 500$ & ${ }^{4} 250$ \\
\hline 1960 & ${ }^{1}<200$ & 5500 & ${ }^{4} 250$ \\
\hline 1961 & ${ }^{1<200}$ & $4,61,000$ & ${ }^{4} 250$ \\
\hline 1962 & ${ }^{1}<200$ & $4,61,000$ & ${ }^{4} 250$ \\
\hline 1963 & ${ }^{1}<200$ & $4,61,000$ & ${ }^{4} 250$ \\
\hline 1964 & ${ }^{1}<200$ & $4,62,000$ & ${ }^{4} 250$ \\
\hline 1965 & ${ }^{1}<200$ & $4,62,000$ & ${ }^{4} 4,000$ \\
\hline 1966 & ${ }^{1}<200$ & $4,63,000$ & $4,74,000$ \\
\hline 1967 & ${ }^{1}<200$ & $6,84,000$ & $6,7,84,000$ \\
\hline 1968 & ${ }^{1}<200$ & $6,84,000$ & $6,7,86,000$ \\
\hline 1969 & ${ }^{1}<200$ & $6,84,000$ & $6,7,85,000$ \\
\hline 1970 & ${ }^{1}<200$ & $6,84,000$ & $6,7,84,000$ \\
\hline 1971 & ${ }^{1}<200$ & ${ }^{6} 4,000$ & $6,75,000$ \\
\hline 1972 & ${ }^{1}<200$ & ${ }^{6} 4,000$ & $6,76,000$ \\
\hline 1973 & ${ }^{1}<200$ & 64,000 & $6,75,000$ \\
\hline 1974 & ${ }^{1}<200$ & 65,000 & $6,77,000$ \\
\hline 1975 & ${ }^{1}<200$ & ${ }^{6} 4,000$ & $6,78,000$ \\
\hline 1976 & ${ }^{1<200}$ & ${ }^{6} 4,000$ & $6,78,000$ \\
\hline 1977 & ${ }^{1}<200$ & 64,000 & $6,77,000$ \\
\hline 1978 & ${ }^{1<200}$ & ${ }^{6} 6,000$ & $6,78,000$ \\
\hline 1979 & ${ }^{1}<200$ & ${ }^{6} 6,000$ & ${ }^{6} 6,000$ \\
\hline 1980 & ${ }^{1}<200$ & $(6,000)^{6} 4,000$ & ${ }^{6} 4,000$ \\
\hline
\end{tabular}

\begin{tabular}{|c|c|c|c|}
\hline Year & $\begin{array}{l}\text { Detrital Valley } \\
\text { (acre-ft/yr) }\end{array}$ & $\begin{array}{c}\text { Hualapai Valley } \\
\text { (acre-ft/yr) }\end{array}$ & $\begin{array}{c}\text { Sacramento Valley } \\
\text { (acre-ft/yr) }\end{array}$ \\
\hline 1981 & $1<200$ & $(5,000)^{6} 6,000$ & 65,000 \\
\hline 1982 & $1<200$ & ${ }^{6} 5,000$ & ${ }^{6} 2,000$ \\
\hline 1983 & ${ }^{1}<200$ & ${ }^{6} 5,000$ & ${ }^{6} 2,000$ \\
\hline 1984 & ${ }^{1}<200$ & 65,000 & ${ }^{6} 2,000$ \\
\hline 1985 & ${ }^{1<200}$ & ${ }^{6} 5,000$ & ${ }^{6} 2,000$ \\
\hline 1986 & ${ }^{1}<200$ & ${ }^{6} 5,000$ & ${ }^{6} 2,000$ \\
\hline 1987 & ${ }^{1}<200$ & $(6,000){ }^{6} 5,000$ & ${ }^{6} 2,000$ \\
\hline 1988 & ${ }^{1}<200$ & 65,000 & ${ }^{6} 2,000$ \\
\hline 1989 & ${ }^{1<200}$ & ${ }^{6} 6,000$ & ${ }^{6} 2,000$ \\
\hline 1990 & ${ }^{1}<200$ & ${ }^{6} 6,000$ & ${ }^{6} 2,000$ \\
\hline 1991 & ${ }^{9} 200$ & ${ }^{9} 4,400$ & ${ }^{9} 1,800$ \\
\hline 1992 & ${ }^{9} 200$ & 95,400 & ${ }^{9} 2,000$ \\
\hline 1993 & ${ }^{9} 200$ & 95,400 & ${ }^{9} 2,000$ \\
\hline 1994 & ${ }^{9} 200$ & ${ }^{9} 6,000$ & ${ }^{9} 2,200$ \\
\hline 1995 & ${ }^{9} 200$ & ${ }^{9} 6,300$ & ${ }^{9} 2,300$ \\
\hline 1996 & ${ }^{9} 200$ & ${ }^{9} 7,000$ & ${ }^{9} 2,400$ \\
\hline 1997 & ${ }^{9} 200$ & ${ }^{9} 6,900$ & ${ }^{9} 2,200$ \\
\hline 1998 & ${ }^{9} 200$ & ${ }^{9} 6,800$ & ${ }^{9} 2,000$ \\
\hline 1999 & ${ }^{9} 200$ & ${ }^{9} 7,500$ & ${ }^{9} 2,700$ \\
\hline 2000 & ${ }^{9} 200$ & ${ }^{9} 8,200$ & ${ }^{9} 2,700$ \\
\hline 2001 & ${ }^{10} 200$ & ${ }^{10} 8,000$ & ${ }^{10} 2,800$ \\
\hline 2002 & ${ }^{10} 300$ & ${ }^{10} 8,500$ & ${ }^{10} 2,900$ \\
\hline 2003 & ${ }^{10} 300$ & ${ }^{10} 8,400$ & ${ }^{10} 2,600$ \\
\hline 2004 & ${ }^{10} 300$ & ${ }^{10} 8,400$ & ${ }^{10} 2,900$ \\
\hline 2005 & ${ }^{10} 300$ & ${ }^{10} 9,100$ & ${ }^{10} 2,700$ \\
\hline 2006 & ${ }^{11}<300$ & ${ }^{11} 9,500$ & ${ }^{11} 3,600$ \\
\hline 2007 & ${ }^{12}<300$ & ${ }^{12} 9,800$ & ${ }^{12,13} 4,500$ \\
\hline 2008 & ${ }^{12}<300$ & ${ }^{12} 9,800$ & ${ }^{12,13} 4,500$ \\
\hline
\end{tabular}

${ }^{1}$ Inferred by assuming historic water use less than first-reported values. ${ }^{2}$ Inferred assuming no major water use prior to first-reported values.

${ }^{3}$ Gillespie and Bentley (1971).

${ }^{4}$ Cox and others (1968).

${ }^{5}$ Estimated on the basis of large yield reported for one well in valley.

${ }^{6}$ Anning and Duet (1994)

${ }^{7} \mathrm{Pfaff}$ and Clay (1981).

${ }^{8}$ Babcock and others $(1969,1970,1972)$.

${ }^{9}$ Tadayon (2005).

${ }^{10}$ Compiled using the same methods as Tadayon (2005).

${ }^{11}$ Estimated as the mean of 2005 and 2007-08 values.

${ }^{12}$ Values from this study, reported as mean for 2007-08 values.

${ }^{13}$ Increase caused by inclusion of 1,900 ac- $\mathrm{ft} / \mathrm{yr}$ industrial water use. 


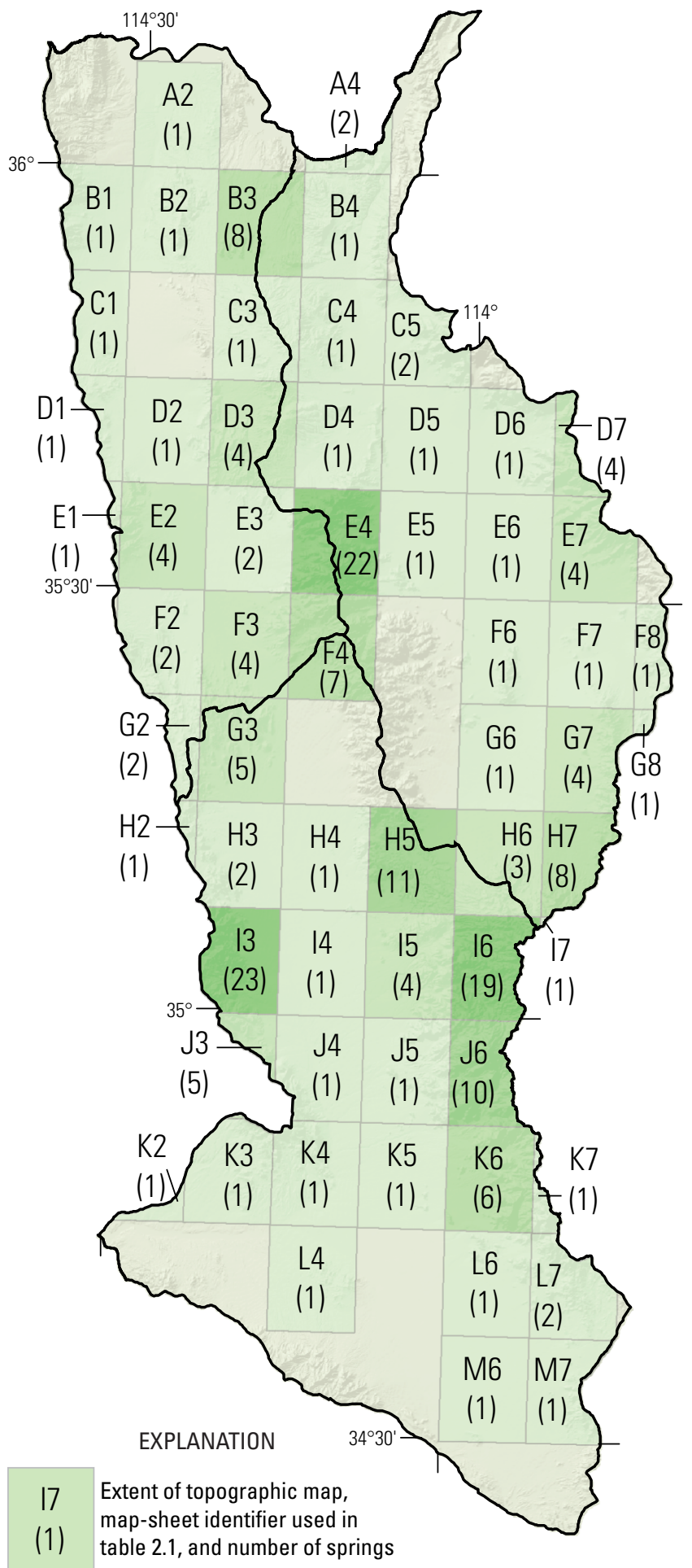

Number of springs identified on sheet

1 23

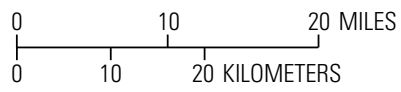

Base modified from U.S. Geological Survey 1:100,000 scale digital data
1,000 acre-ft/yr or more, mostly in support of municipal and domestic water uses (Anning and Duet, 1994). By 1991, almost all groundwater pumping withdrawals were for municipal and domestic water uses. Groundwater withdrawals increased steadily from 4,400 acre-ft/yr in 1991 to about 9,800 acre-ft/yr in 2008. Total cumulative groundwater withdrawn from the Hualapai Valley alluvial aquifer from 1940 to 2008 is estimated to be about 270,000 acre-ft.

Sacramento Valley alluvial aquifer groundwater withdrawals were $250 \mathrm{acre}-\mathrm{ft} / \mathrm{yr}$ or less from 1940 to 1964 (Cox and others, 1968). Groundwater withdrawals increased to 4,000 acre-ft/yr in 1965 and increased again from 1966 to 1978 $(4,000-8,000$ acre-ft/yr), mostly in support of municipal and domestic water uses for City of Kingman and the surrounding area (Anning and Duet, 1994). Groundwater withdrawals decreased substantially from 1978 to 1982 (from 8,000 to 2,000 acre-ft/yr), likely the result of the City of Kingman limiting pumping of its well field in the volcanic rocks on the east side of Sacramento Valley, owing to depletion of the resource (Rascona, 1991). Since 1982, withdrawals have remained near $2,000 \mathrm{acre}-\mathrm{ft} / \mathrm{yr}$, although they have been increasing during that time (Anning and Duet, 1994; Tadayon, 2005). Total cumulative groundwater withdrawn from the Sacramento Valley alluvial aquifer from 1940 to 2008 was about 170,000 acre-ft.

\section{Appendix 2. Inventory of Springs}

Small springs exist in upland areas of the study area because of shallow groundwater discharging either through fractures in mountain-block bedrock or along zones of perched water. A visual inspection of USGS topographic maps (fig. 2.1; table 2.1) was completed to estimate total annual groundwater discharge from upland springs. Field verification of these springs, or an assessment about the completeness of this inventory, is beyond the scope of this report. Springs were excluded if their elevation and surrounding terrain indicated they most likely discharge Lake Mead bank-storage water or alluvialaquifer groundwater. Within the study area, 204 springs were identified, of which 19 percent, 29 percent, and 52 percent were in Detrital, Hualapai, and Sacramento Valleys, respectively.

Median upland-spring discharge for each valley was estimated by using spring-discharge data from the Arizona Department of Water Resources (2009b). Four springs in Detrital Valley had a median discharge of $4.5 \mathrm{gal} / \mathrm{min}$. Seventeen springs in Hualapai Valley had a median discharge of $3.0 \mathrm{gal} / \mathrm{min}$. Fifty-eight springs in Sacramento Valley had a median discharge of $3.0 \mathrm{gpm}$. Multiplying these values by the number of inventoried springs in each valley resulted in upland-spring discharge estimates of $300 \mathrm{acre}-\mathrm{ft} / \mathrm{yr}$ for Detrital Valley, 300 acre-ft/yr for Hualapai Valley, and 500 acre-ft/yr for Sacramento Valley. These values are low compared to total recharge and runoff in the study area (about 4 percent).

Several springs have been identified in the vicinity of Lake Mead (table 2.2). These are discussed in the "Springs Near Lake Mead" section. They are divided into springs that discharge above and below the maximum possible surfacewater elevation of Lake Mead. 
Table 2.1. Inventory of upland springs, identified by visual inspection of U.S. Geological Survey 1:24,000 topographic map sheets, Mohave County, Arizona. Names provided where available, otherwise general location indicated.

[**, multiple springs within the same vicinity; DV, Detrital valley; HV, Hualapai Valley; SV, Sacramento Valley; NW, northwest; NE, northeast; SW, southwest; SE, southeast]

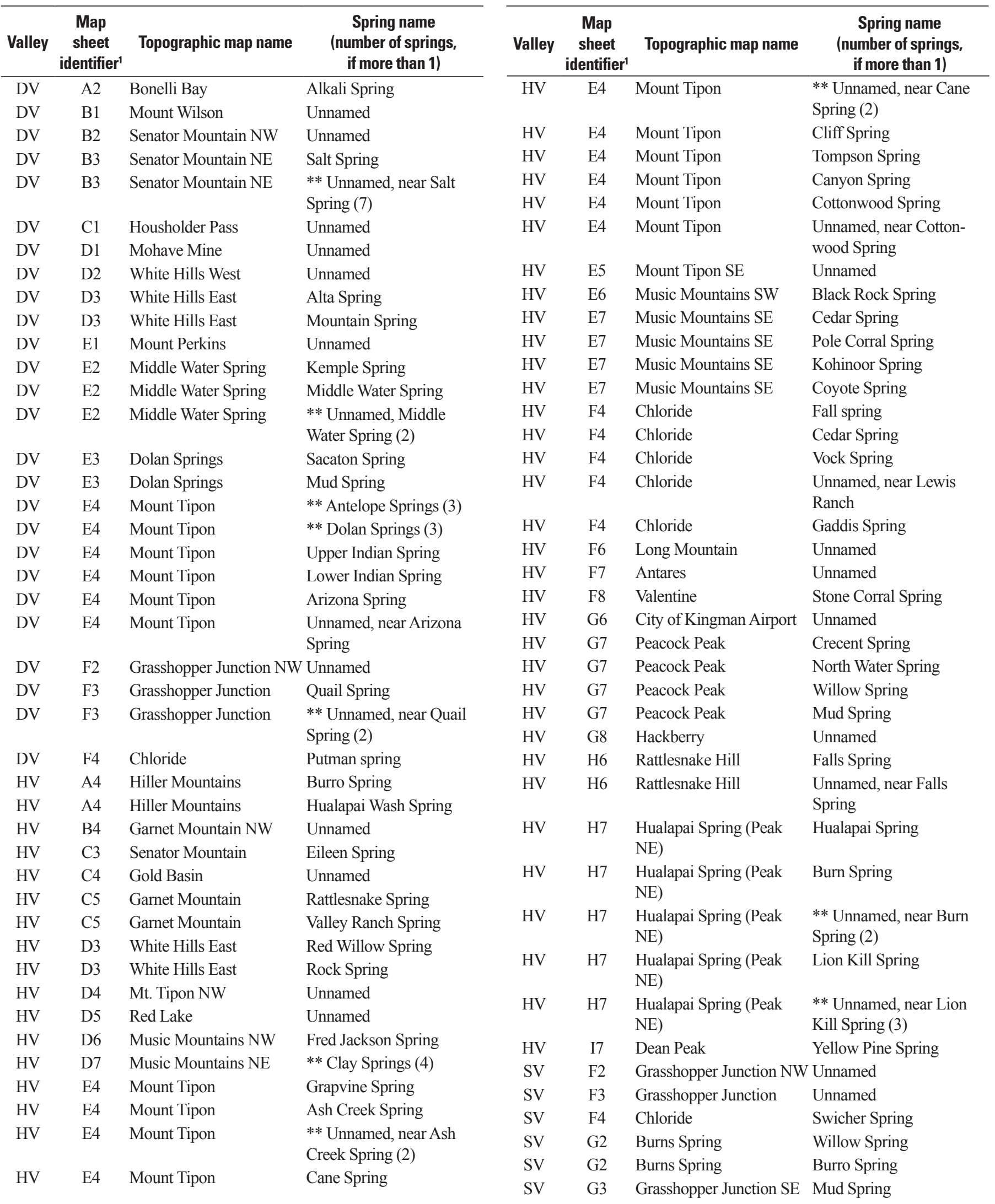


Table 2.1. Inventory of upland springs, identified by visual inspection of U.S. Geological Survey 1:24,000 topographic map sheets, Mohave County, Arizona. Names provided where available, otherwise general location indicated.-Continued

[**, multiple springs within the same vicinity; DV, Detrital valley; HV, Hualapai Valley; SV, Sacramento Valley; NW, northwest; NE, northeast; SW, southwest; SE, southeast]

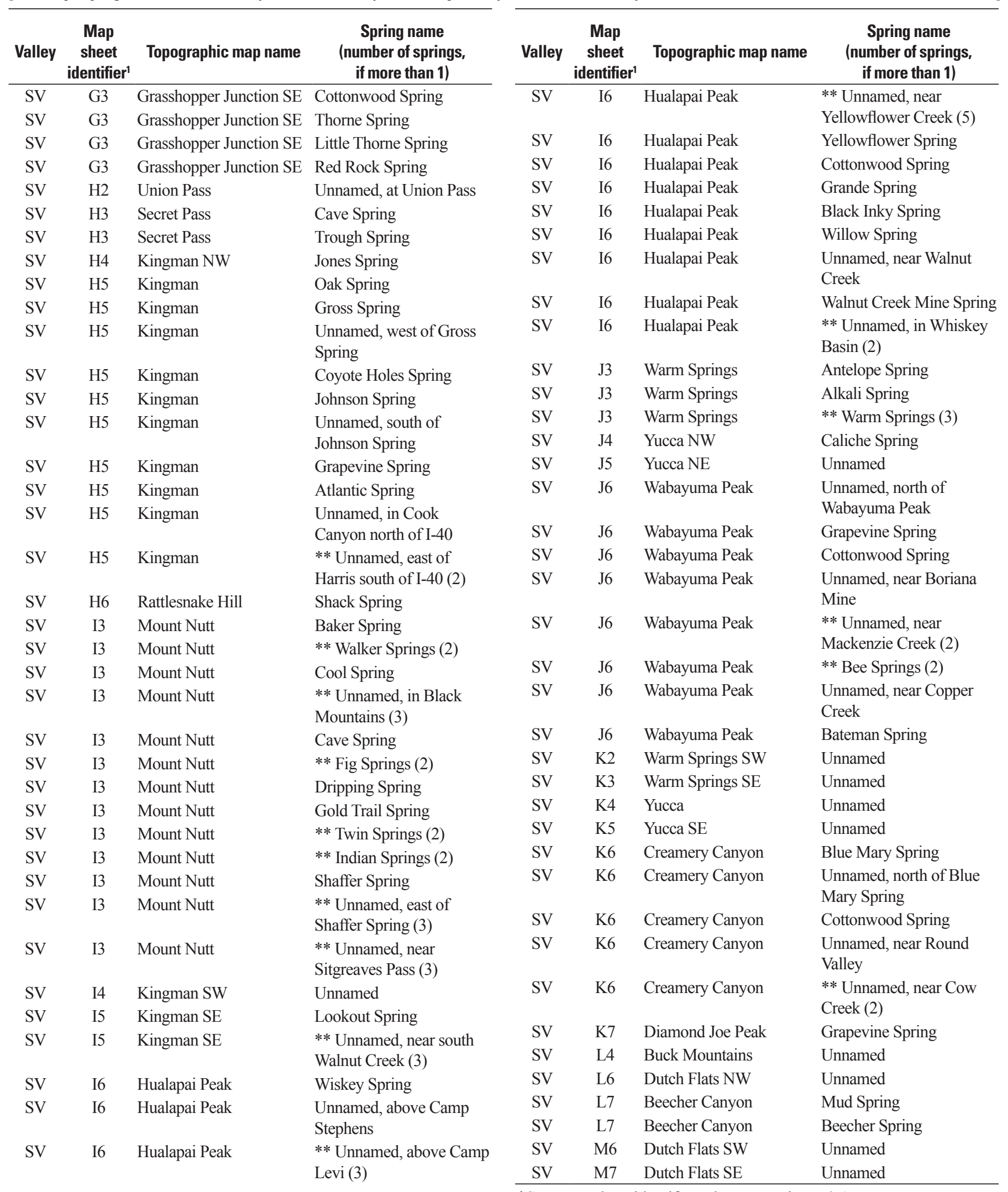

${ }^{1}$ Corresponds to identifiers shown on Figure 2.1. 
Table 2.2. Inventory of springs near the southern shoreline of Lake Mead, Mohave County, Arizona; includes measured discharge, where available. [discharge data 1960-80 from Laney (1979); ?, unknown month for discharge value]

\begin{tabular}{|c|c|c|c|c|}
\hline Spring Name & $\begin{array}{c}\text { Elevation, } \\
\text { in feet above mean } \\
\text { sea level }\end{array}$ & $\begin{array}{l}\text { Rock type from which } \\
\text { spring discharges }\end{array}$ & $\begin{array}{l}\text { Latitude and longitude } \\
\text { (North American Datum, 1927) }\end{array}$ & $\begin{array}{c}\text { Discharge } \\
\text { (month/year: gallons per } \\
\text { minute) }\end{array}$ \\
\hline \multicolumn{5}{|c|}{ Above Lake Mead maximum lake-surface elevation } \\
\hline Salt Spring & 1,390 & Alluvium & $35^{\circ} 59^{\prime} 19^{\prime \prime} \mathrm{N} 114^{\circ} 15^{\prime} 19^{\prime \prime} \mathrm{W}$ & $\begin{array}{l}\text { 5/73: } 9 ; 5 / 75: 2 \\
\text { 2/08: } 8 ; 5 / 09: 0\end{array}$ \\
\hline Alkali Spring & 1,220 & Muddy Creek Formation & $36^{\circ} 02^{\prime} 54^{\prime \prime} \mathrm{N} 114^{\circ} 27^{\prime} 21^{\prime \prime} \mathrm{W}$ & 4/08: 0 \\
\hline \multicolumn{5}{|c|}{ Below Lake Mead maximum lake-surface elevation } \\
\hline $\begin{array}{l}\text { Hualapai Wash } \\
\text { Seeps }\end{array}$ & 1,214 & Muddy Creek Formation & $36^{\circ} 00^{\prime} 43^{\prime \prime} \mathrm{N} 114^{\circ} 07^{\prime} 36^{\prime \prime} \mathrm{W}$ & 4/08: 0 \\
\hline Granite Cove & 1,197 & Granite & $36^{\circ} 00^{\prime} 42^{\prime \prime} \mathrm{N} 114^{\circ} 08^{\prime} 56^{\prime \prime} \mathrm{W}$ & 2/76: $25 ; 4 / 08: 0$ \\
\hline
\end{tabular}


This page left intentionally blank. 
3 